\title{
Differences in Western North Pacific Tropical Cyclone Activity among Three EI Niño Phases
}

\author{
JINJIE SONG \\ State Key Laboratory of Severe Weather, Chinese Academy of Meteorological Sciences, Beijing, China \\ PHILIP J. KLOTZBACH \\ Department of Atmospheric Science, Colorado State University, Fort Collins, Colorado \\ YIHONG DUAN \\ State Key Laboratory of Severe Weather, Chinese Academy of Meteorological Sciences, Beijing, China
}

(Manuscript received 9 March 2020, in final form 2 July 2020)

\begin{abstract}
The impacts of El Niño on tropical cyclone (TC) activity over the western North Pacific (WNP) are examined through investigation of three types of tropical Pacific warming episodes according to where the maximum sea surface temperature (SST) anomalies occur in the equatorial Pacific: the eastern Pacific El Niño (EPE), the central Pacific El Niño (CPE), and the mixed El Niño (ME). More TCs form over the eastern part of the WNP in all three El Niño types, whereas the frequency of TCs over the western part of the WNP increases as the peak SST anomalies migrate from east to west. Although TCs more frequently recurve at higher latitudes during EPE and CPE, the most frequent region for recurving is much closer to the East Asian continent in CPE years than in EPE years. In contrast, more TCs track westward and threaten the Philippines in ME years. The increased TC genesis over the western part of the WNP can be explained by enhanced lowlevel relative vorticity, reduced vertical wind shear, and increased maximum potential intensity during CPE and increased midlevel moisture during EPE and ME. This increase is further related to updraft anomalies near the date line driven by an anomalous Walker circulation and an anomalous low-level cyclonic circulation over the WNP. The TC track differences among the different El Niño types are linked to the east-west shift of the western Pacific subtropical high, possibly caused by an anomalous Hadley circulation from $120^{\circ}$ to $130^{\circ} \mathrm{E}$ that is strongly coupled with the anomalous Walker circulation.
\end{abstract}

\section{Introduction}

Tropical cyclones (TCs) are among the most destructive natural phenomena, causing strong winds, high levels of storm surge, and heavy rains that pose a severe threat to life and property in coastal regions. The western North Pacific (WNP) is the most TC-active basin in the world, where approximately one-third of global TCs develop on average (Chan 2005). These TCs also tend to reach higher intensities than TCs in other basins (Chan 2005). Given the heightened awareness of climate change, increased attention has been focused on WNP TC variability during the past several decades (Walsh et al. 2016). Numerous studies have investigated the spatiotemporal variability of WNP TC activity as

\footnotetext{
Corresponding author: Jinjie Song, songjinjie@qq.com
}

modulated by various climate modes as well as climate change (Emanuel 2018; Knutson et al. 2019, 2020; Walsh et al. 2019).

It is by now well accepted that El Niño-Southern Oscillation (ENSO) is a major factor influencing WNP TC activity on interannual time scales. ENSO has been shown to modulate WNP TC frequency, intensity, formation location, and lifespan (Emanuel 2018). ENSO is a leading mode of natural climate variability and is associated with changes in both sea surface temperature (SST) over the tropical Pacific (as well as other basins) and the position and strength of the Walker circulation. Earlier studies investigating ENSO showed that El Niño events were characterized by strong SST anomalies (SSTAs) in the eastern equatorial Pacific as well as a weaker and eastward-shifted Walker circulation (Rasmusson and Carpenter 1982; Philander 1990). Several previous studies have shown 
that ENSO does not significantly impact WNP TC number but strongly modulates its mean TC genesis location (Lander 1994; Chan 1985, 2000; Saunders et al. 2000; Wang and Chan 2002; Wu et al. 2004; Camargo and Sobel 2005; Camargo et al. 2007a; Zhao et al. 2010; $\mathrm{Li}$ and Zhou 2012). WNP TC formation tends to shift more eastward and equatorward in El Niño years, due to warmer SST, greater relative humidity, and lower vertical wind shear over the southeastern quadrant of the WNP relative to La Niña years (Wang and Chan 2002). Moreover, in El Niño years, due to the migration in the average TC genesis location and the change in the mean steering flow, TCs tend to recurve northeastward and reach higher latitudes (Wang and Chan 2002; Camargo et al. 2007a). Since changes in the large-scale environmental conditions are related to the temporal evolution of an ENSO event, there are also differences in WNP TC activity depending on whether the El Niño event is developing or decaying (Camargo and Sobel 2005; Li and Zhou 2012). There is also a lead-lag relationship between ENSO and WNP TC activity, which may be related to the autocorrelation of ENSO indices (Camargo and Sobel 2005; Li and Zhou 2012).

More recently, El Niño events have been documented to exhibit different SSTA patterns (Ashok et al. 2007; Ashok and Yamagata 2009; Kao and Yu 2009; Kug et al. 2009; Yeh et al. 2009), including two distinct types: the eastern Pacific El Niño (EPE) where the maximum SST warming occurs between $\sim 150^{\circ}$ and $\sim 90^{\circ} \mathrm{W}$ (the Niño-3 region) and the central Pacific El Niño (CPE) where the peak SST warming is located between $\sim 160^{\circ} \mathrm{E}$ and $\sim 150^{\circ} \mathrm{W}$ (the Niño-4 region). Several studies have shown that WNP TC activity exhibits different characteristics in CPE and EPE (Chen and Tam 2010; Kim et al. 2011; Pradhan et al. 2011; Zhang et al. 2012; Ha et al. 2012; C. Wang et al. 2013; Jin et al. 2013; Patricola et al. 2018; Wu et al. 2018; Zhao and Wang 2019). WNP TC frequency is significantly related to the ENSO Modoki index, with more frequent TC formations in CPE events (Chen and Tam 2010). Since the Walker circulation is westwardshifted in CPE relative to EPE, the region favorable for TC genesis and development extends through the northwestern part of the WNP, which further leads to a higher probability of TCs making landfall in East Asia (Kim et al. 2011).

Besides EPE and CPE, there is a third type of El Niño that features SSTA characteristics between an EPE and a CPE (Kug et al. 2009; Yu and Kim 2013; Timmermann et al. 2018). This so-called mixed El Niño (ME) exhibits maximum positive SSTAs from around $\sim 150^{\circ}$ to $\sim 120^{\circ} \mathrm{W}$, which roughly corresponds to the Niño-3.4 region (Kug et al. 2009). Note that the ME SSTA pattern is consistent with the fourth empirical orthogonal function (EOF) mode of tropical Pacific SSTA in 1979-2004 derived by Ashok et al. (2007). This indicates that the ME pattern is orthogonal to (e.g., independent of) the other two El Niño patterns, which are shown as the first two EOF modes in Ashok et al. (2007), rather than a combination of EPE and CPE types. When compared with EPE or CPE events, ME events show different evolution characteristics and produce distinct global large-scale circulation anomalies that are different from those induced by EPE or CPE (Murphy et al. 2014; Li et al. 2015; Andreoli et al. 2017).

Murphy et al. (2014) showed varied impacts of these three El Niño phases on rainfall patterns for Pacific island countries. Although EPE events have much greater impacts on rainfall than $\mathrm{CPE}$ and $\mathrm{ME}$, there are definite differences between CPE and ME events, including a farther eastward shift of rainfall anomalies and a larger equatorward migration of the intertropical convergence zone and the South Pacific convergence zone during ME than during CPE. Andreoli et al. (2017) reported that despite the general El Niño-generated dryness over equatorial South America, the mechanisms forcing the negative precipitation anomalies are different among the three El Niño phases. The main contributors are the stronger and weaker Walker circulation with downward motion over equatorial South America during CPE and ME, respectively, whereas it is the local response to the northward SSTA gradient during EPE.

Despite these studies showing differences in the largescale atmospheric response to the three types of El Niño, the characteristics of WNP TC activity during ME have yet to be investigated. Consequently, it is unclear what the similarities and differences are in WNP TC activity between ME and the other two El Niño phases. If we consider EPE, ME, and CPE as a continuum of El Niño types (Giese and Ray 2011; Johnson 2013), are the features related to WNP TC activity in ME years just a combination of those in EPE and CPE years? Or, since EPE, ME, and CPE are shown to be three independent modes in EOF decomposition (Ashok et al. 2007), are the characteristics of WNP TC activity during ME entirely different from those during the other two phases? Therefore the objective of this study is to investigate the potential mechanisms forcing the ME modulation of WNP TC activity, as well as examining both its differences and its similarities to EPE and CPE. In addition, because of the southeastward migration of TC genesis, TCs in El Niño years generally track over warm waters for a longer time and reach a higher intensity than TCs forming in La Niña years (Chan 2005; Camargo and Sobel 2005), which significantly increases both the frequency of intense TCs and basinwide accumulated cyclone energy (ACE; Bell et al. 2000). These results mean that TC intensity is considerably influenced by TC 
TABLE 1. List of WNP TC seasons from 1970 to 2019 that were categorized as EPE, CPE, ME, and La Niña.

\begin{tabular}{ll}
\hline \hline ENSO type & \multicolumn{1}{c}{ Years } \\
\hline EPE & $1972,1982,1997,2009,2014,2015$ \\
CPE & $1994,2004,2006,2018,2019$ \\
ME & $1977,1986,1987,1991,2002$ \\
La Niña & $1970,1971,1973,1974,1975,1984,1985,1988$, \\
& $1998,1999,2000,2007,2010,2011$ \\
\hline
\end{tabular}

genesis location during these different ENSO phases. Thus we focus on the changes in the genesis and track of WNP TCs, rather than other metrics.

The remainder of the paper is arranged as follows. Section 2 provides a description of the methodology and the data applied in this analysis. Section 3 presents the classification approach used to differentiate the ENSO types (EPE, CPE, ME, and La Niña). Section 4 describes observational characteristics of WNP TC genesis and track for the different ENSO phases. Section 5 discusses the influence of the large-scale environment on WNP TC formation and track in EPE, ME, and CPE years. Our analysis does not isolate the ENSO-originated processes but focuses on the typical features of WNP TC activity and large-scale environmental conditions that appear in these El Niño types. The conclusions and discussions of this study are given in section 6 .

\section{Data and methods}

WNP TC best track data used in this study are from the Joint Typhoon Warning Center (JTWC) as compiled in the International Best Track Archive for Climate Stewardship version 4 (Knapp et al. 2010), including TC central position and intensity at 6-h intervals. Because of the poor quality of JTWC data prior to the 1970s (Chu et al. 2002) and the uncertainty in observing tropical depressions (Klotzbach and Landsea 2015), this study only considers TCs with an intensity greater than $34 \mathrm{kt}$ $\left(1 \mathrm{kt} \approx 0.51 \mathrm{~m} \mathrm{~s}^{-1}\right)$ over the period from $1970-2019$. The analysis is focused on the TC-active season over the WNP from June to November, with $\sim 85 \%$ of TCs climatologically occurring during this period (Song and Klotzbach 2019).

Monthly mean SST data are provided by the National Oceanic and Atmospheric Administration Extended Reconstructed SST v5 (Huang et al. 2017), with a horizontal resolution of $2^{\circ} \times 2^{\circ}$. Monthly mean atmospheric data are obtained from the National Centers for Environmental Prediction-National Center for Atmospheric Research reanalysis over a $2.5^{\circ} \times 2.5^{\circ}$ grid (Kalnay et al. 1996), followed by a cubic spline interpolation to a $2^{\circ} \times 2^{\circ}$ grid for computing the maximum potential intensity (MPI; Emanuel
1988) and the genesis potential index (GPI; Emanuel and Nolan 2004). All oceanic and atmospheric variables are calculated as seasonal averages from June to November.

All of the anomalies noted in this study refer to deviations from the corresponding climatological (19702019) means. The significance of each anomaly can be estimated by the two-sample $t$ test for unpaired data (Snedecor and Cochran 1989). The similarity of two spatial distributions is measured by the pattern correlation whose significance is estimated by Student's $t$ test.

\section{Classification of different ENSO phases}

Since this study focuses on the simultaneous impact of ENSO on WNP TC activity, different ENSO phases are identified through three SSTA indices averaged between June and November. They are defined as follows: Niño-3 $\left(5^{\circ} \mathrm{S}-5^{\circ} \mathrm{N}, 150^{\circ}-90^{\circ} \mathrm{W}\right)$, Niño-3.4 $\left(5^{\circ} \mathrm{S}-5^{\circ} \mathrm{N}\right.$, $\left.170^{\circ}-120^{\circ} \mathrm{W}\right)$, and Niño-4 $\left(5^{\circ} \mathrm{S}-5^{\circ} \mathrm{N}, 160^{\circ} \mathrm{E}-150^{\circ} \mathrm{W}\right)$ (Trenberth 1997). An El Niño event is defined whenever the areal mean SSTA over any one of the above Niño regions is greater than $0.5^{\circ} \mathrm{C}$ for the June-November average, and a La Niña event is defined whenever the areal mean SSTA over any one of the above regions is less than $-0.5^{\circ} \mathrm{C}$. El Niño years are then classified as EPE, CPE, and ME according to the largest average SSTA occurring in the Niño-3, Niño-4, and Niño-3.4 regions, respectively. Table 1 displays events classified as EPE, CPE, ME, and La Niña. This classification is similar to that of Murphy et al. (2014), with the exception that the method here applies $0.5^{\circ} \mathrm{C}$ as the threshold to declare an event instead of one standard deviation. Note that the classification of El Niño types in our study is slightly different from those in previous papers (e.g., Yu et al. 2012), primarily owing to the different seasons considered. Although ENSO tends to peak during the boreal winter, WNP TC frequency is at its minimum during this season. Additionally, the sign and amplitude of equatorial Pacific SSTA varies with month during the same year, and consequently the ENSO type identified in one season is likely not to be consistent with those identified in other seasons during the same year (Wang and Chan 2002). Numerous publications (e.g., Wang and Chan 2002; Camargo and Sobel 2005; Chen and Tam 2010; Kim et al. 2011; Pradhan et al. 2011; Zhang et al. 2012; Ha et al. 2012; C. Wang et al. 2013; Jin et al. 2013; Patricola et al. 2018; Wu et al. 2018; Zhao and Wang 2019) have investigated the effect of ENSO on WNP TC activity by using ENSO indices averaged during the TC-active season (e.g., boreal summer and autumn).

Figure 1 displays the mean June-November SSTA patterns for the three El Niño types as well as for La Niña. As expected, the maximum anomalies are east of 

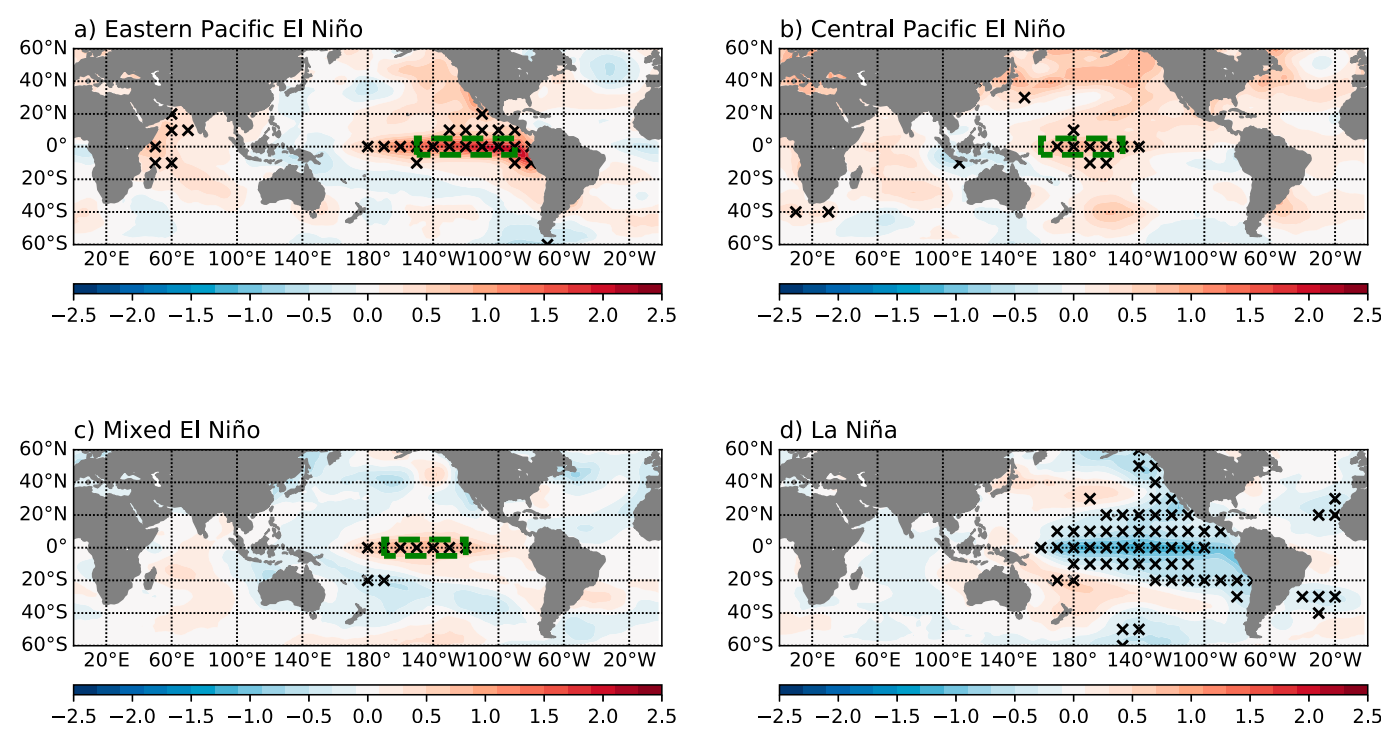

FIG. 1. Mean June-November SST anomalies $\left({ }^{\circ} \mathrm{C}\right)$ for (a) EPE, (b) CPE, (c) ME, and (d) La Niña years. Dashed rectangles indicate the Niño-3, Niño-4, and Niño-3.4 regions in (a), (b), and (c), respectively. Black crosses denote SST anomalies that are significant at the 0.05 level.

$100^{\circ} \mathrm{W}$ for $\mathrm{EPE}$, around $140^{\circ} \mathrm{W}$ for $\mathrm{ME}$, and near the date line for CPE, which verifies the feasibility and validity of the classification scheme used in this study. Consistent with Murphy et al. (2014), the magnitude of the positive SSTAs becomes smaller as the maximum warming shifts from east to west. During EPE and ME, positive SSTAs are concentrated over the tropical central-eastern Pacific and the Indian Ocean (IO), while negative SSTAs occur from the tropical western Pacific to the subtropical central Pacific (Figs. 1a,c). Figure 1a shows significant positive SSTAs over the tropical eastern IO, which can be linked to the strong relationship between the Indian Ocean dipole (IOD) and EPE after the 1970s (Yuan and Li 2008; Yuan et al. 2012). By comparison, as was found in Kug et al. (2009), anomalously warm waters during CPE extend from the subtropical eastern Pacific to the tropical central Pacific. CPE events tend to have the largest meridional areal extent of positive SSTAs among the three El Niño phases. This pattern likely results from the strong positive correlation between the Pacific meridional mode, which describes the meridional variability in the tropical eastern Pacific and CPE (Stuecker 2018). Finally, there are no significant SSTAs over the tropical North Atlantic (TNA), which is defined as $0^{\circ}-15^{\circ} \mathrm{N}, 80^{\circ} \mathrm{W}-$ $20^{\circ} \mathrm{E}$ by L. Wang et al. (2017), regardless of the El Niño type investigated (Figs. 1a-c). Note that there is a robust lagged relationship between TNA SST and ENSO variability, which indicates the potential for TNA SSTAs to trigger an ENSO event, particularly a CPE event, through an Atlantic capacitor effect mechanism (e.g., Ham et al. 2013a; L. Wang et al. 2017). However, there is no significant relationship between the TNA SST during June-November and the simultaneous Niño-3/Niño-4/ Niño-3.4 SST, with correlation coefficients of -0.06 , 0.12 , and -0.05 , respectively. None of these correlations are significant at the 0.05 level. Additionally, although spring SSTs over other basins can modulate the WNP large-scale environment and consequently WNP TC formation during summer and autumn (Ham et al. 2013a,b; C. Wang et al. 2013; Zhan et al. 2013; Huo et al. 2015; Wang 2016; Cao et al. 2018), there are almost no significant spring SSTAs over the globe in any of the three El Niño types (figure not shown).

We further carry out an empirical orthogonal function (EOF) analysis on detrended June-November SST over the tropical Pacific $\left(30^{\circ} \mathrm{S}-30^{\circ} \mathrm{N}, 100^{\circ} \mathrm{E}-60^{\circ} \mathrm{W}\right)$ from 1970 to 2019 (Fig. 2). The features of the three dominant EOF modes are consistent with the aforementioned SSTA pattern during EPE, CPE, and ME, with pattern correlations of $0.94(p<0.01), 0.60(p<0.01)$, and $0.42(p<0.01)$, respectively. The EPE, CPE, and ME years identified in this study roughly correspond to the local maxima in the first, second, and third principal component time series, respectively. These findings support our classification approach for separating the different El Niño types. Additionally, we speculate that the ME pattern is orthogonal to the other two El Niño patterns, rather than simply a combination of the EPE and CPE patterns. Note that the ME pattern is derived as the third mode in this 
a) First Mode $(55.3 \%)$
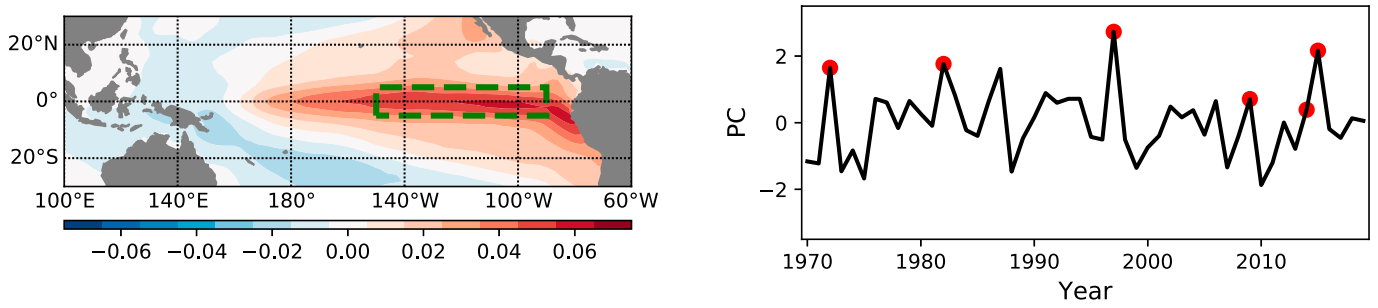

b) Second Mode (11.8\%)
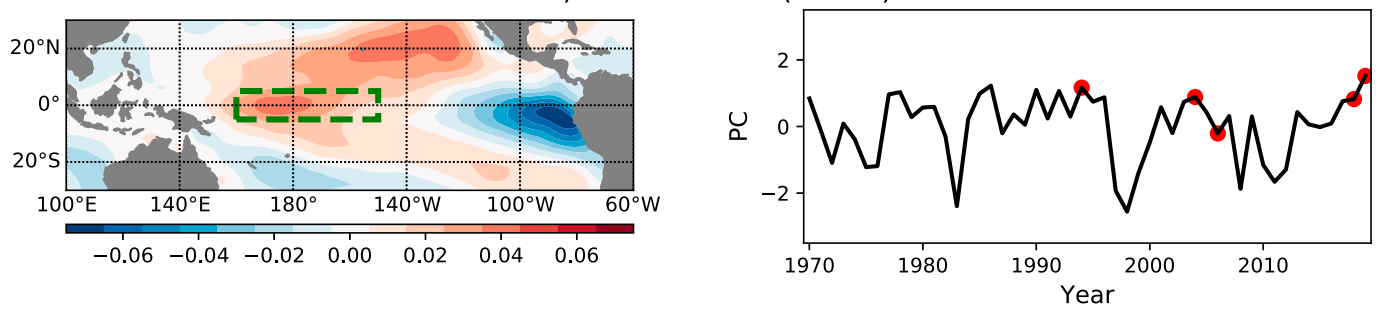

c) Third Mode (7.6\%)
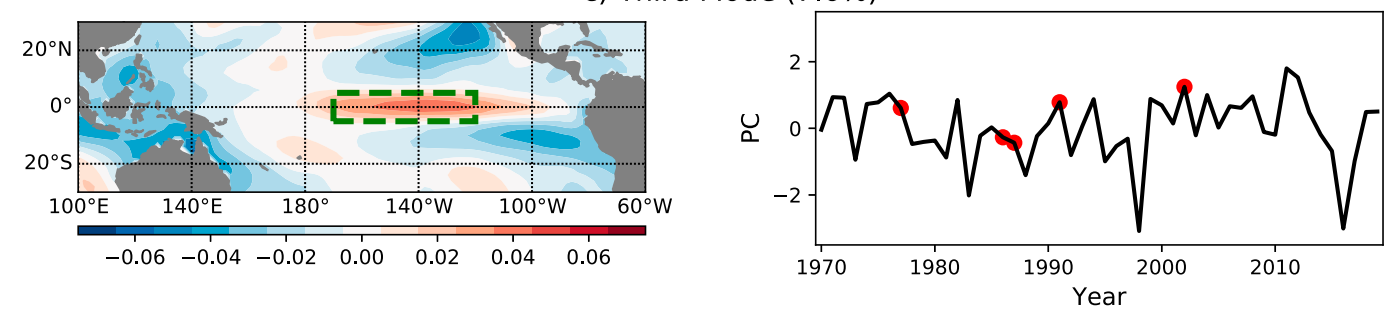

FIG. 2. (a)-(c) Top three modes of detrended June-November tropical Pacific SST (1970-2019). Shown are (left) the spatial empirical orthogonal function patterns and (right) the principal component time series. Dashed rectangles indicate the Niño-3, Niño-4, and Niño-3.4 regions in (a), (b), and (c), respectively. Red circles denote the identified EPE, CPE, and ME years in (a), (b), and (c), respectively.

study, whereas it was found to be the fourth mode in Ashok et al. (2007). This difference is likely caused by our use of detrended SSTs and the relatively longer study period.

\section{WNP TC activity among different ENSO phases}

\section{a. TC genesis}

Consistent with previous studies (Chen and Tam 2010; Kim et al. 2011), there are distinct spatial features in WNP TC genesis anomalies between EPE and CPE events (Figs. 3a,b). Over the eastern part of the WNP (east of $150^{\circ} \mathrm{E}$ ), although TCs form more frequently in both types of El Niño events, the genesis anomalies are of a greater magnitude and are shifted southward during EPE relative to CPE. Over the western part of the WNP (west of $150^{\circ} \mathrm{E}$ ), genesis anomalies between the two types of El Niño events are of the opposite sign north of $10^{\circ} \mathrm{N}$ and of the same sign south of $10^{\circ} \mathrm{N}$. There are significantly fewer and more TC formations over the western part of the WNP during EPE and CPE, respectively.

The spatial characteristics of WNP TC genesis anomalies during ME also exhibit enhanced TC formation over the eastern portion of the WNP and suppressed TC formation over the western portion of the WNP. The pattern correlation of genesis anomalies between ME and EPE $(r=0.89, p<0.01)$ is much greater than that between ME and CPE $(r=0.24, p<$ 0.01 ), indicating that the spatial distribution of genesis anomalies during ME is more similar to EPE than to CPE (Fig. 3c). When comparing ME with EPE, the magnitude of negative TC genesis anomalies in the western portion of the WNP and the magnitude of positive TC genesis anomalies in the eastern portion of the WNP become relatively smaller and less significant. Overall, TCs occur more frequently east of $150^{\circ} \mathrm{E}$ in all El Niño phases. In contrast, as the El Niño-induced warming center of Pacific SSTAs shifts from east to west, there is a transition from lesser to greater frequency of TCs forming west of $150^{\circ} \mathrm{E}$. La Niña events are characterized by suppressed TC formation east of $150^{\circ} \mathrm{E}$ and enhanced TC formation west of $150^{\circ} \mathrm{E}$ (Fig. 3d). The pattern correlations of genesis anomalies between $\mathrm{La}$ Niña and EPE, CPE, and ME are $-0.78(p<0.01),-0.37$ $(p<0.01)$, and $-0.69(p<0.01)$, respectively, indicating that the spatial structure of genesis anomalies during $\mathrm{La}$ Niña most closely mirrors those of EPE. 


\section{Genesis Density Anomaly}
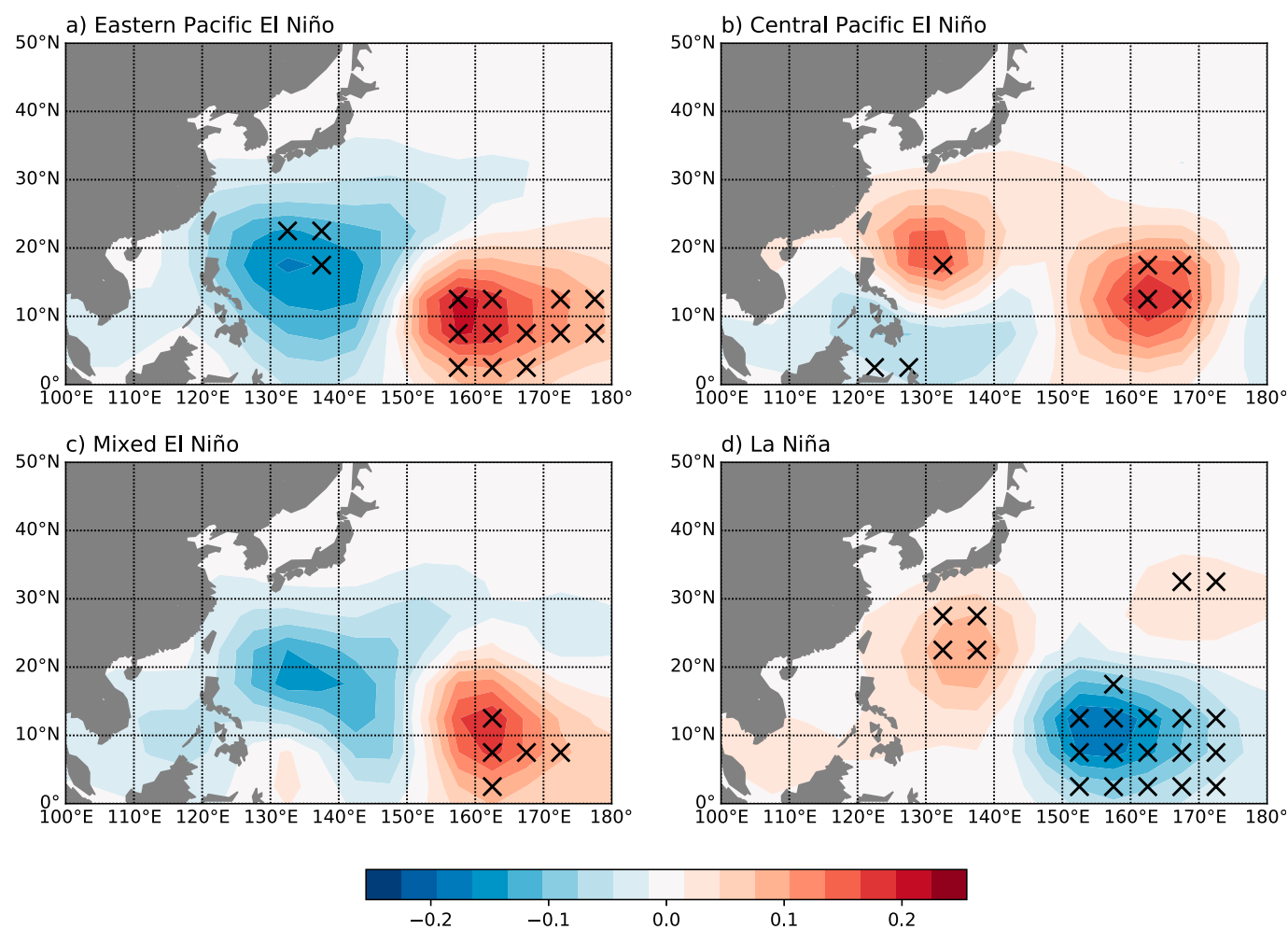

FIG. 3. Average genesis density anomalies in June-November over a $5^{\circ} \times 5^{\circ}$ grid for (a) EPE, (b) CPE, (c) ME, and

(d) La Niña years. Black crosses denote that anomalies are significantly different from zero at the 0.05 level.

\section{b. TC track}

There are distinct patterns in WNP TC track density anomalies during each of these different ENSO phases (Fig. 4). During EPE years, there are positive track density anomalies east of $130^{\circ} \mathrm{E}$, with the largest anomalies concentrated in the latitudinal belt from $10^{\circ}$ to $20^{\circ} \mathrm{N}$ (Fig. 4a). In EPE years, more TCs recurve away from the East Asian continent and subsequently move northward until making landfall over Japan or dissipating over the extratropical Pacific. This feature is not consistent with Kim et al. (2011), who showed negative track density anomalies north of $25^{\circ} \mathrm{N}$ during EPE. This difference is likely caused by the differences in the classifications of ENSO phases as well as the definitions used for the TC-active season. Note that this track type is also considered as one of the main paths for WNP TCs by Zhang et al. (2012). Furthermore, the negative track density anomalies west of $130^{\circ} \mathrm{E}$ indicate fewer TCs making landfall over most of the coastal countries of East and Southeast Asia except Japan. In contrast, there are significant negative track density anomalies east of $130^{\circ} \mathrm{E}$ during La Niña years. These anomalies (Fig. 4d) are almost a mirror image of El Niño years (Figs. 4a-c), having pattern correlations with those during EPE, CPE, and ME of $-0.67(p<0.01),-0.65(p<0.01)$, and -0.52 $(p<0.01)$, respectively.

The track density anomalies during CPE or ME are somewhat different from those during EPE or La Niña (Figs. 4b,c). Similar to previous publications (Kim et al. 2011; Zhang et al. 2012; Jin et al. 2013), positive track density anomalies occur over almost all of the WNP during CPE years, indicating more TCs recurving near the East Asian continent and threatening northern China, the Korean peninsula, and Japan (Fig. 4b). In contrast, the region with positive track anomalies is concentrated south of $30^{\circ} \mathrm{N}$ and extends westward to $130^{\circ} \mathrm{E}$ during ME years (Fig. 4c).

To investigate the differences in TC tracks among different El Niño types in more detail, Figs. 5d-s displays the track density anomalies in individual El Niño years. TC track density anomalies exhibit similar features to the composites described above in most years. In particular, during ME, more TCs move westward and make landfall over the Philippines, whereas there are fewer TCs making landfall in other Pacific coastal regions. Exceptions include the 1982 and 1991 TC seasons, which exhibit a combination of EPE and ME track 

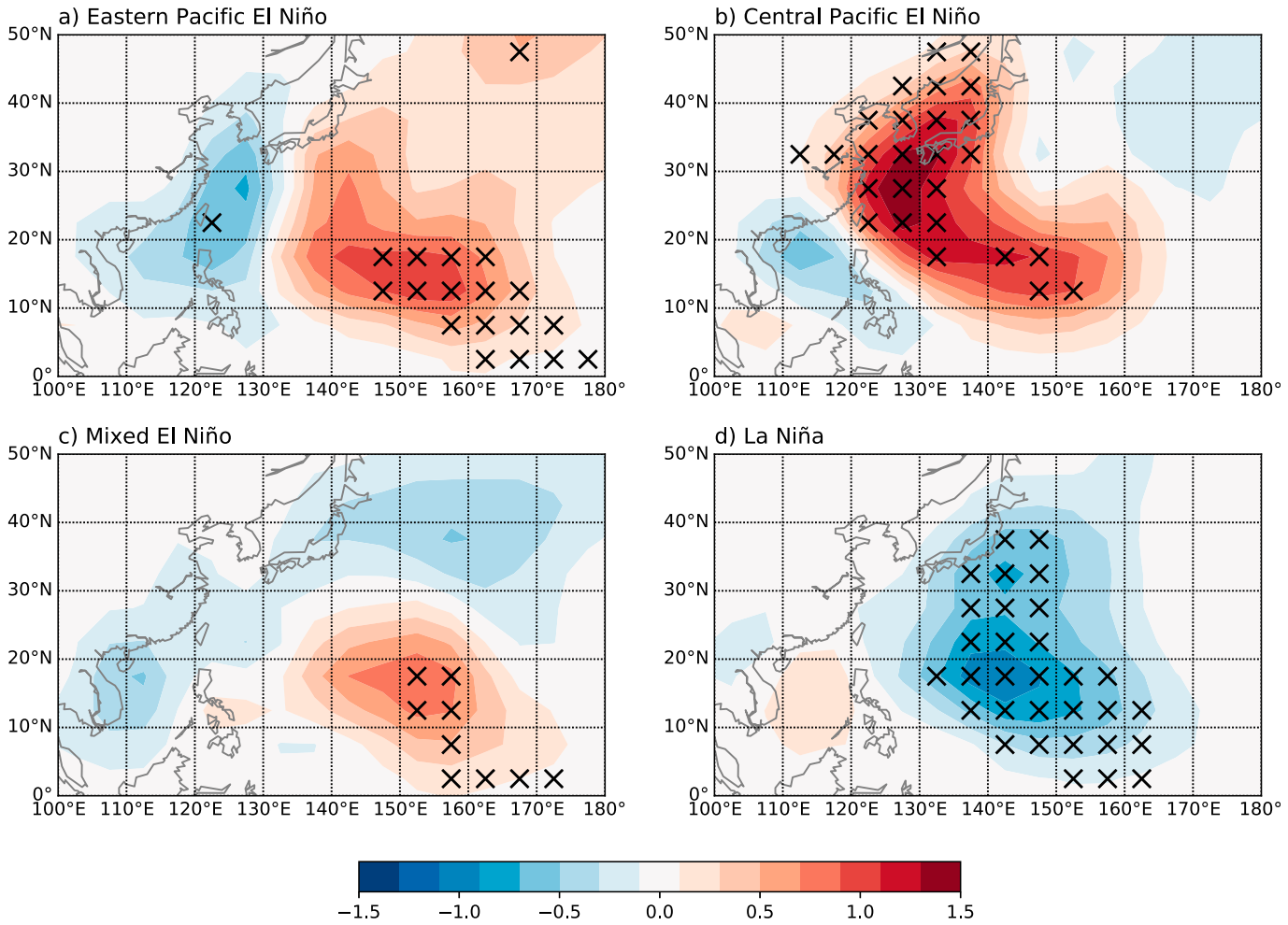

FIG. 4. As in Fig. 3, but for the track density anomaly.

density anomalies, the 2002 TC season in which the track density anomaly is much closer to the CPE composite than the ME composite, and the 2014 TC season in which the track density anomaly is much closer to the CPE composite than the EPE composite. Some exceptions can be explained by comparable SSTAs over different Niño regions. For example, the 1991 (2014) season had SSTAs of $0.60^{\circ}$ and $0.63^{\circ} \mathrm{C}\left(0.64^{\circ}\right.$ and $\left.0.53^{\circ} \mathrm{C}\right)$ over the Niño-3 and Niño-4 regions, respectively. To better extract the features of each El Niño type, we also composite the track anomalies weighted by the Niño-3 SSTA, Niño-4 SSTA, and Niño-3.4 SSTA for EPE, CPE, and ME, respectively (Figs. 5a-c). The composite weighted track anomalies represent similar patterns to the unweighted averages (Figs. 4a-c).

\section{Large-scale environmental conditions for different EI Niño types}

\section{a. Environmental conditions influencing TC formation}

Figure 6 shows GPI anomalies in June-November for the different ENSO types. These GPI anomalies are broadly consistent with the corresponding TC genesis anomalies. In EPE years, there are significant positive and negative GPI anomalies east and west of $150^{\circ} \mathrm{E}$, respectively. In CPE events, the region with positive GPI anomalies extends from the southeastern quadrant of the WNP to the east of Taiwan, while significantly negative GPI anomalies occur over the South China Sea (SCS). ME years exhibit significant positive GPI anomalies that are concentrated over the southeastern corner of the WNP. These positive GPI anomalies are of a relatively smaller extent than for either the EPE or CPE. Although there is a large area with suppressed GPI west of $150^{\circ} \mathrm{E}$, the negative anomalies are not statistically significant in ME years. In La Niña years, similar to what was found for TC genesis anomalies, GPI anomalies are nearly the opposite of those experienced in EPE years, with a pattern correlation of -0.68 ( $p<$ $0.01)$. These findings imply that the diversity of TC genesis in different ENSO phases can be well captured by the corresponding large-scale environments, as has been documented in previous papers (Camargo and Sobel 2005; Kim et al. 2011).

Figures 7-9 display anomalies of four environmental variables constituting the GPI, including MPI, $600-\mathrm{hPa}$ relative humidity (RH600), $850-\mathrm{hPa}$ relative vorticity (VOR850), and 850-200-hPa vertical wind shear (SHR), as well as their importance for the three El Niño types. 

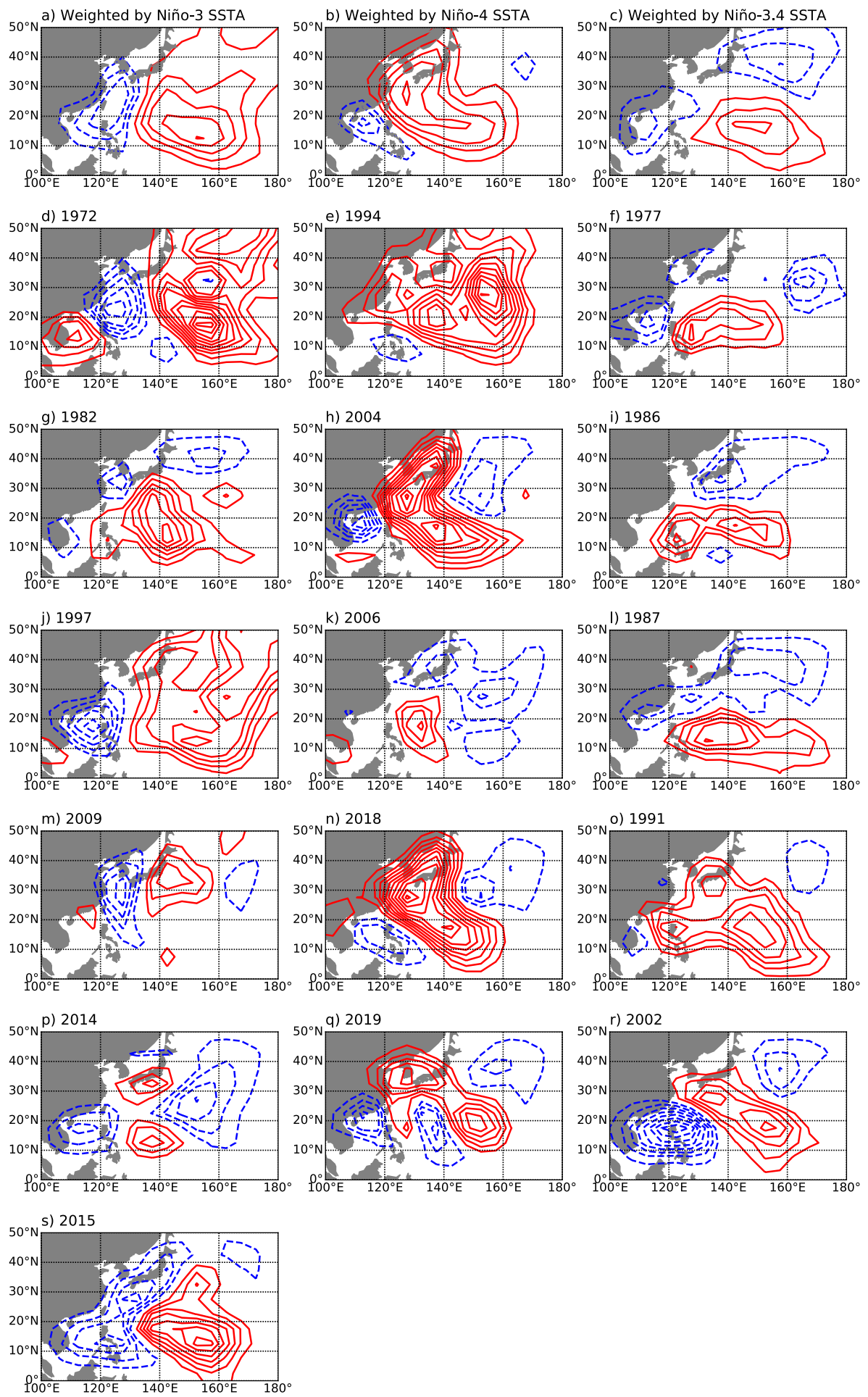

FIG. 5. (a)-(s) Track density anomalies in June-November for (left) six EPE years, (center) five ME years, and (right) five CPE years. In (a)-(c), the track density anomalies are weighted by the means in the corresponding Niño regions. The contour interval in each panel is 0.3 . 


\section{Genesis Potential Index Anomaly}
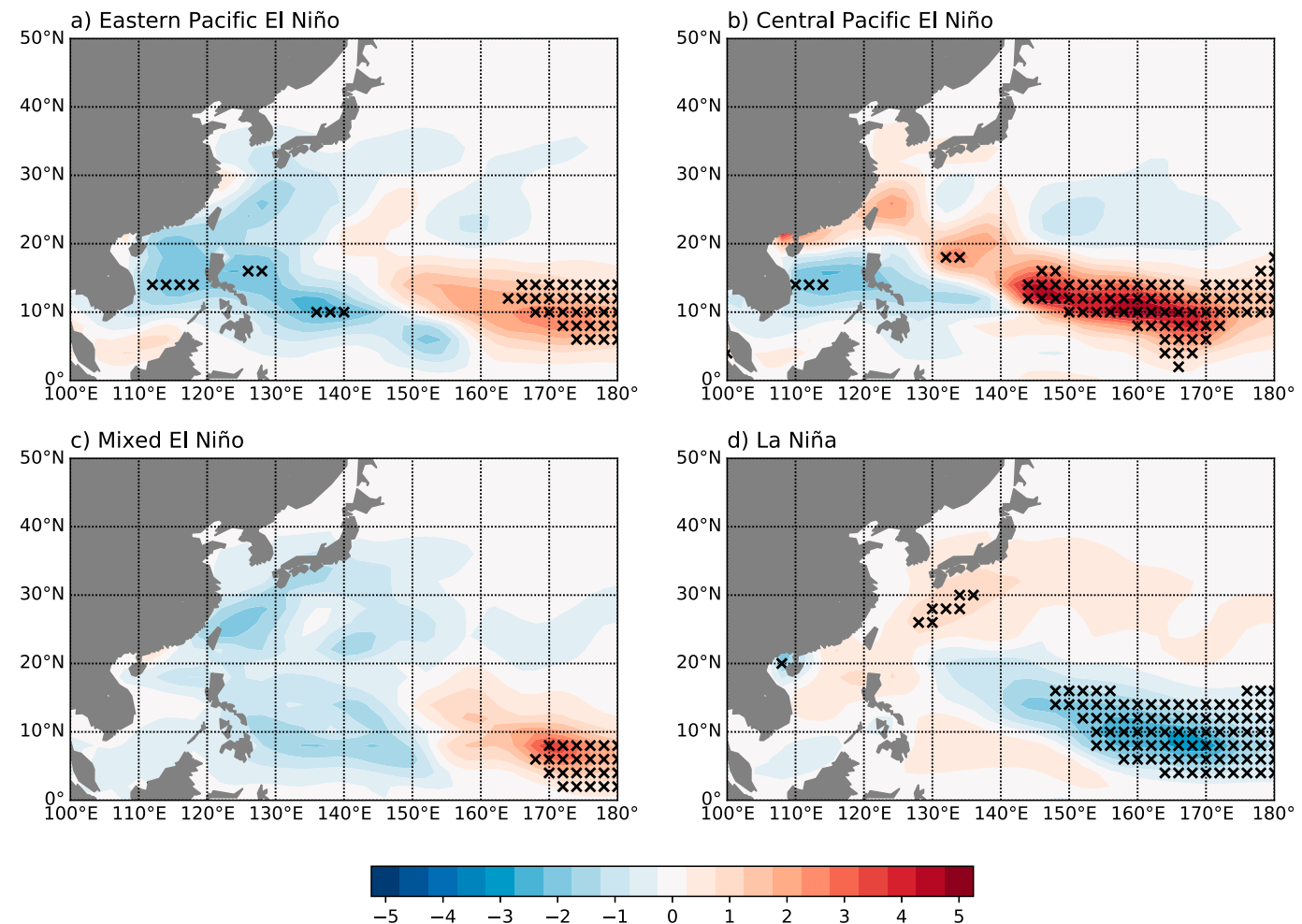

FIG. 6. As in Fig. 3, but for the genesis potential index anomaly. The horizontal resolution is $2^{\circ} \times 2^{\circ}$.

To assess the individual importance of these four variables, we recalculate the GPI using the long-term climatology of one of the variables but the original, annually varying values for the other three variables. We carried out this procedure for each of the four variables, followed by recalculating GPI anomalies for the different El Niño years. If one variable plays a dominant role, the area of significant GPI anomalies is considerably reduced from the original GPI when that variable is fixed at its long-term climatology.

During EPE years, only small areas of the WNP have significant anomalies in MPI (Fig. 7a). Over the eastern part of the WNP, more frequent TC genesis appears to result from higher RH600, greater VOR850, and lower SHR (Figs. 7c,e,g). Significantly greater GPI anomalies occur when each of the RH600, VOR850, and SHR fields is fixed at its long-term climatology (Figs. 7d,f,h), indicating that there is no sole environmental factor primarily controlling TC genesis. By contrast, over the western part of the WNP, fewer TC formations during EPE years are predominantly caused by a much drier midtroposphere (Fig. 7c), since there are only slight GPI anomalies when RH600 is fixed (Fig. 7d), compared with significant GPI anomalies when RH600 is varied (Fig. 6a). The significant negative GPI anomalies in
Figs. $7 f$ and $7 \mathrm{~h}$ indicate that VOR850 and SHR play much smaller roles than RH600.

During CPE years, there is significantly higher MPI, greater VOR850, and lower SHR over the tropical Pacific east of $140^{\circ} \mathrm{E}$ (Figs. 8a,e,g). All of these conditions are favorable for TC genesis. Since there are only slight differences in RH600 east of $140^{\circ} \mathrm{E}$, midtroposphere moisture appears to have a relatively small impact on TC formation (Fig. 8c). Compared with significant GPI anomalies when VOR850 is varied (Fig. 6b), there are only slight positive GPI anomalies within $130^{\circ}-140^{\circ} \mathrm{E}$ and $10^{\circ}-20^{\circ} \mathrm{N}$ when VOR850 is fixed as its long-term climatology (Fig. 8f). This same region has significant positive GPI anomalies, regardless of whether MPI, RH600, or SHR is fixed at long-term climatology (Figs. 6b and $8 \mathrm{~b}, \mathrm{~d}, \mathrm{~h})$. These findings indicate that favorable conditions for TC formation in this domain are primarily determined by larger VOR850. Additionally, over the SCS, there are significant RH600 and SHR differences, indicating that less frequent $\mathrm{TC}$ formation is induced by both reduced RH600 and enhanced SHR (Figs. 8c,g).

The anomaly patterns of large-scale environmental variables in ME years resemble those in EPE years, but are of a smaller magnitude (Figs. 9a,c,e,g). In ME years, there are higher RH600, greater VOR850, and lower 


\section{Eastern Pacific El Niño Years}
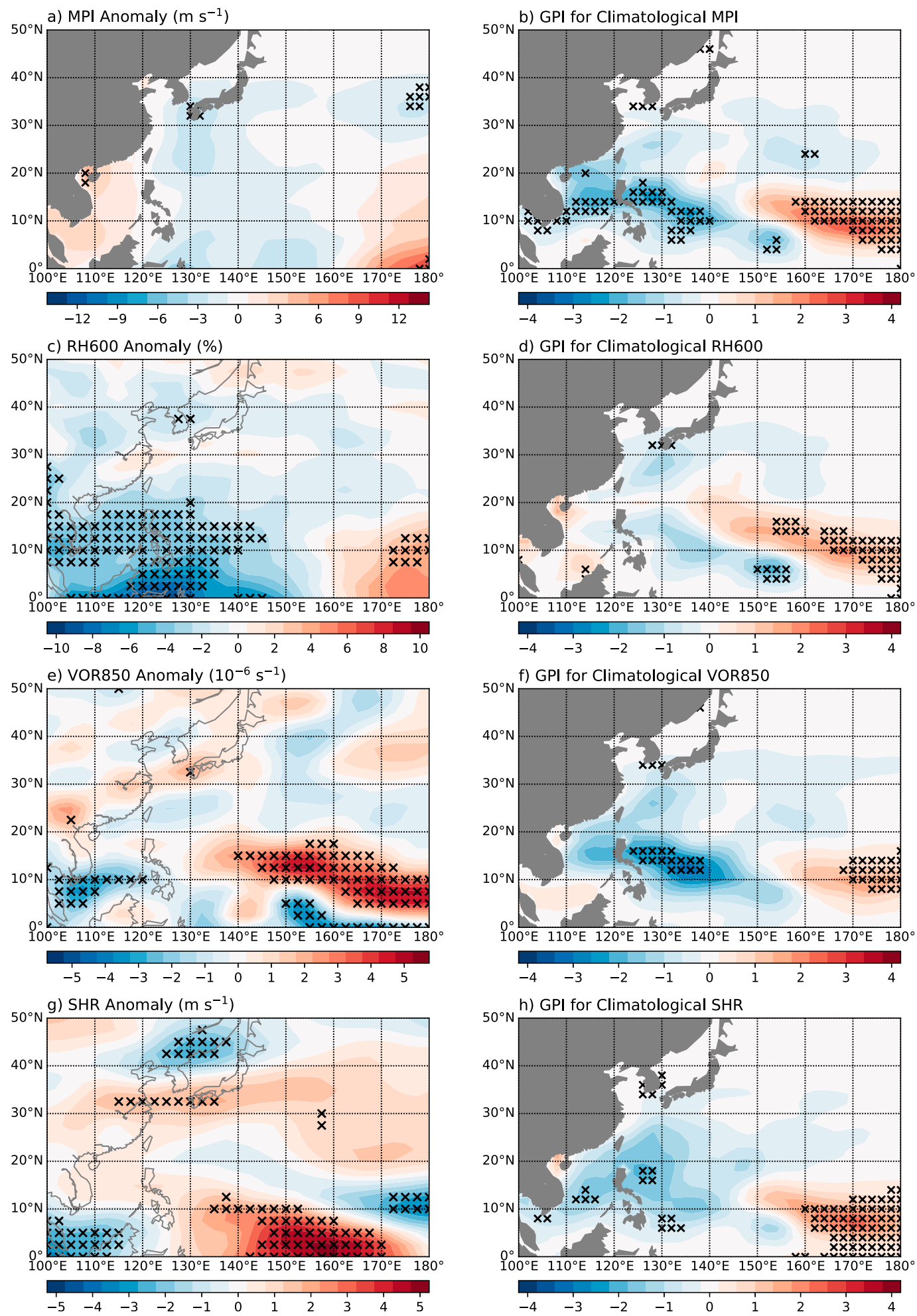

FIG. 7. (left) Anomalies of environmental variables and (right) GPI anomalies when keeping one variable at its climatological value and allowing the other variables to vary in EPE years for (a),(b) MPI, (c),(d) 600-hPa relative humidity, (e),(f) 850-hPa relative vorticity, and (g),(h) 850-200-hPa vertical wind shear. Black crosses indicate that the anomalies are significant at the 0.05 level. 


\section{Central Pacific El Niño Years}
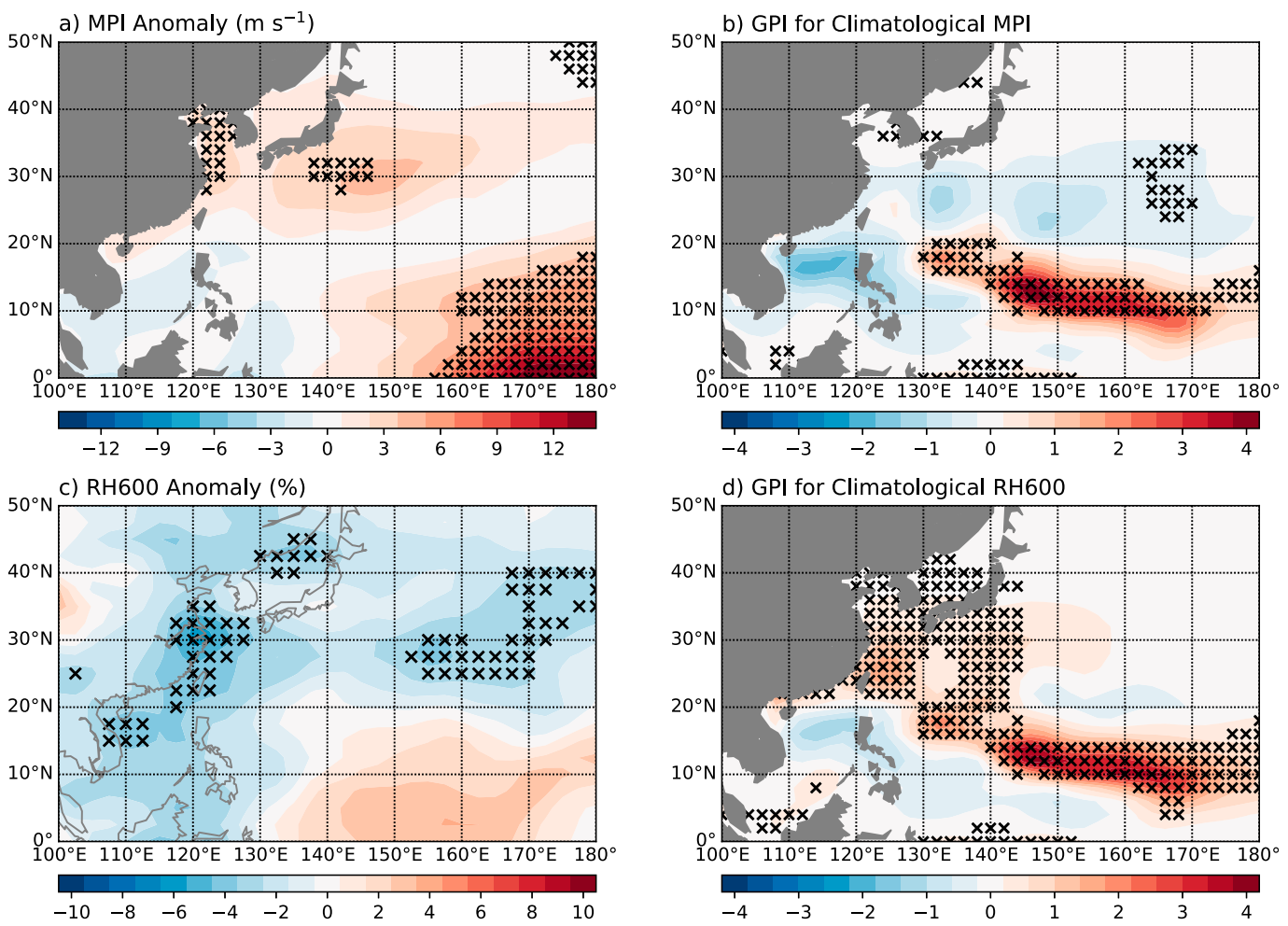

$50^{\circ} \mathrm{N}$ d) GPI for Climatological RH600
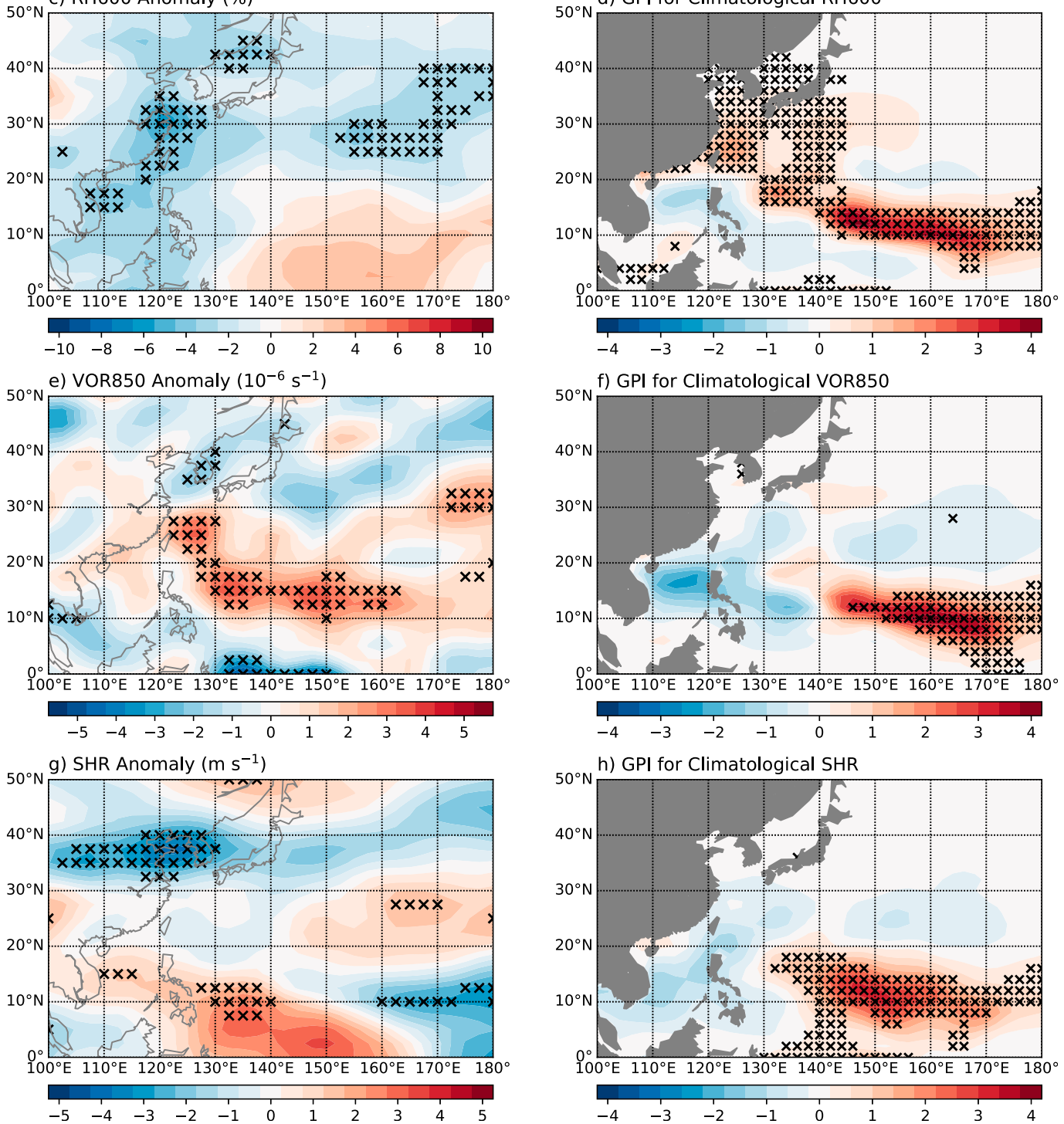

FIG. 8. As in Fig. 7, but for CPE years. 
Mixed El Niño Years
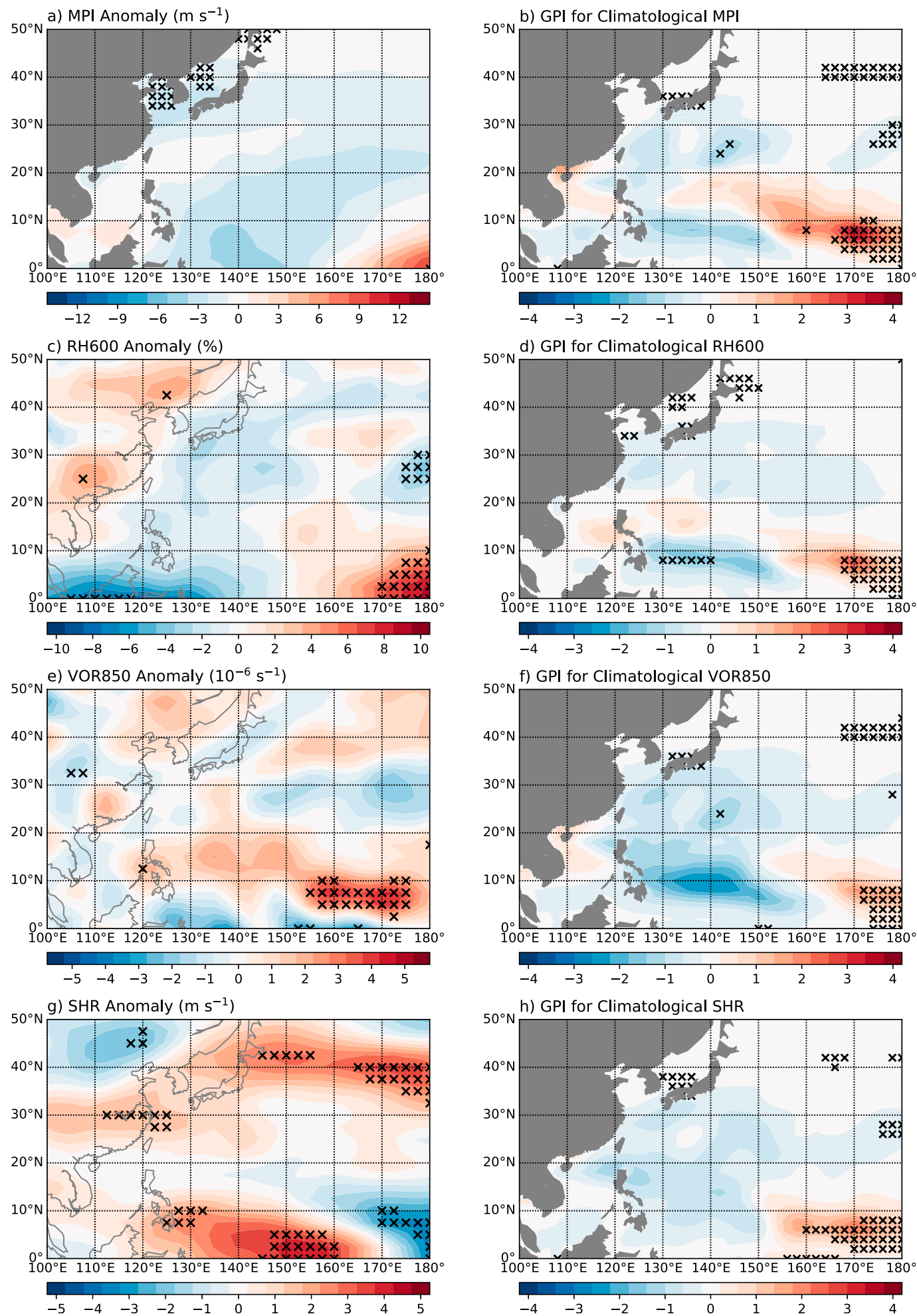

FIG. 9. As in Fig. 7, but for ME years. 
SHR over the southeastern corner of the WNP $\left(160^{\circ} \mathrm{E}-\right.$ $180^{\circ}, 0^{\circ}-15^{\circ} \mathrm{N}$; Figs. $\left.9 \mathrm{c}, \mathrm{e}, \mathrm{g}\right)$, which all favor TC development. These results mean that in this region, there is no single variable primarily modulating TC genesis for ME, similar to what we found for EPE. There are almost no significant anomalies for MPI, RH600, and VOR850 west of $150^{\circ} \mathrm{E}$, indicating that these factors likely only cause minor changes in TC formation (Figs. 9a,c,e). Although significantly enhanced SHR is observed over most of the equatorial and extratropical Pacific in ME years, its effects are minor considering that few TCs typically form in these regions.

It has been well documented that the Walker circulation is somewhat different in EPE and CPE events (Kim et al. 2011; B. Wang et al. 2017). Figure 10 displays the climatological Walker circulation and composites of the anomalous Walker circulation for the three El Niño types investigated in this study. Climatologically, the Walker circulation is constituted by upward motion around $120^{\circ} \mathrm{E}$ with downward motion west of the date line (Fig. 10a). As expected, the peak anomalous ascending motion migrates westward as the maximum positive SSTA shifts from east to west (Figs. 10b-d). The Walker circulation for all three El Niño phases features anomalous upward motion near the date line, enhancing TC formation over the southeastern quadrant of the WNP.

In EPE years, there are maximum anomalous updrafts over the Niño-3 region and two maximum anomalous downdrafts within $120^{\circ}-130^{\circ} \mathrm{E}$ and $80^{\circ}-70^{\circ} \mathrm{W}$, comprising a two-cell Walker circulation pattern (Fig. 10b). Note that the magnitudes of the vertical motion anomalies in the western downdraft cell are the strongest among the three El Niño phases. The strong anomalous downward motion significantly reduces midlevel relative humidity and suppresses TC formation over the western part of the WNP (Kim et al. 2011).

In CPE years, there is an anomalous single Walker cell feature with maximum anomalous ascending motion over the Niño-4 region and maximum anomalous descending motion near the westernmost boundary of the Pacific Ocean (around $120^{\circ} \mathrm{E}$; Fig. 10c). In contrast, anomalous ascending and descending motion alternate east of $120^{\circ} \mathrm{E}$.

In ME years, the maximum anomalous ascending motion corresponds to the Niño-3.4 region and is much stronger than the anomalous updraft in CPE years (Fig. 10d). There is also a double Walker cell structure in ME years, with two anomalous regions of descending motion at around $120^{\circ} \mathrm{E}$ and $90^{\circ} \mathrm{W}$. There is weaker anomalous downward flow around $120^{\circ} \mathrm{E}$ in $\mathrm{ME}$ years than in EPE and CPE years, indicating a weak Walker cell between the central and western tropical Pacific. We conclude that as the center of the warming SSTAs shifts from east to west, the anomalous descending motion between $120^{\circ}$ and $130^{\circ} \mathrm{E}$ first weakens and then strengthens, as was also seen in the anomalous Walker circulation pattern over $4^{\circ} \mathrm{S}-4^{\circ} \mathrm{N}$ during summer as shown in Andreoli et al. (2017). In comparison, the anomalous downward motion around $90^{\circ} \mathrm{W}$ is much stronger and broader than its western counterpart in ME years.

Figure 11 displays anomalous $850-\mathrm{hPa}$ streamlines for the three El Niño phases. During EPE, there is an anomalous low-level cyclone centered near $15^{\circ} \mathrm{N}, 160^{\circ} \mathrm{E}$, with a horizontal trough along $160^{\circ} \mathrm{E}$, which enhances low-level vorticity and subsequently favors TC formation over the southeastern quadrant of the WNP (Fig. 11a). In contrast, most of the western part of the WNP is primarily influenced by a low-level ridge that suppresses TC genesis.

During CPE, a large anomalous cyclonic circulation is centered at $15^{\circ} \mathrm{N}, 155^{\circ} \mathrm{E}$, with a trough extending from $150^{\circ}$ to $120^{\circ} \mathrm{E}$ in the latitude belt from $10^{\circ}$ to $30^{\circ} \mathrm{N}$ (Fig. 11b), which favors TC genesis over almost all of the entire WNP (Fig. 11b). There is also an anomalous cyclonic circulation centered at $20^{\circ} \mathrm{N}, 140^{\circ} \mathrm{E}$ during ME, but the circulation is of a smaller magnitude than during $\mathrm{CPE}$ within the latitudinal belt of $10^{\circ}-30^{\circ} \mathrm{N}$ (Fig. 11b). A northwest-southeast-oriented trough (from $20^{\circ} \mathrm{N}, 140^{\circ} \mathrm{E}$ to $10^{\circ} \mathrm{N}, 160^{\circ} \mathrm{E}$ ) induces significant positive low-level vorticity and favors TC genesis over the southeastern quadrant of the WNP. Note that although there are some positive eddy geopotential height anomalies over the southeastern quadrant of the WNP during all three El Niño phases, the anomalous circulations are cyclonic and enhance lowlevel vorticity, thereby favoring TC formation.

\section{b. Environmental conditions influencing TC movement}

The track of a TC can be determined by several factors, including the TC genesis location, the steering flow, and the large-scale environment along the TC's path. While Fig. 3 and Figs. 7-9 show the anomalies in TC genesis location and the large-scale environment, respectively, Fig. 12 represents the steering currents. These steering currents are defined as the mean flow between 850 and $300 \mathrm{hPa}$ (Chu et al. 2012), and the areal extent of the western Pacific subtropical high (WPSH), which is considered as the 0 -gpm contour line of the 850hPa eddy geopotential height (Huang et al. 2015) for the climatology and for EPE, CPE, and ME years. Here, the eddy indicates the deviation from the zonal mean. The steering flow shares a generally similar structure in the climatology and in all three El Niño phases, with an anticyclonic circulation characterized by easterlies south of $25^{\circ} \mathrm{N}$ and westerlies north of $25^{\circ} \mathrm{N}$. Compared with climatology, the WPSH retreats eastward during EPE and $\mathrm{CPE}$, but extends westward during ME. 
a) Climatology
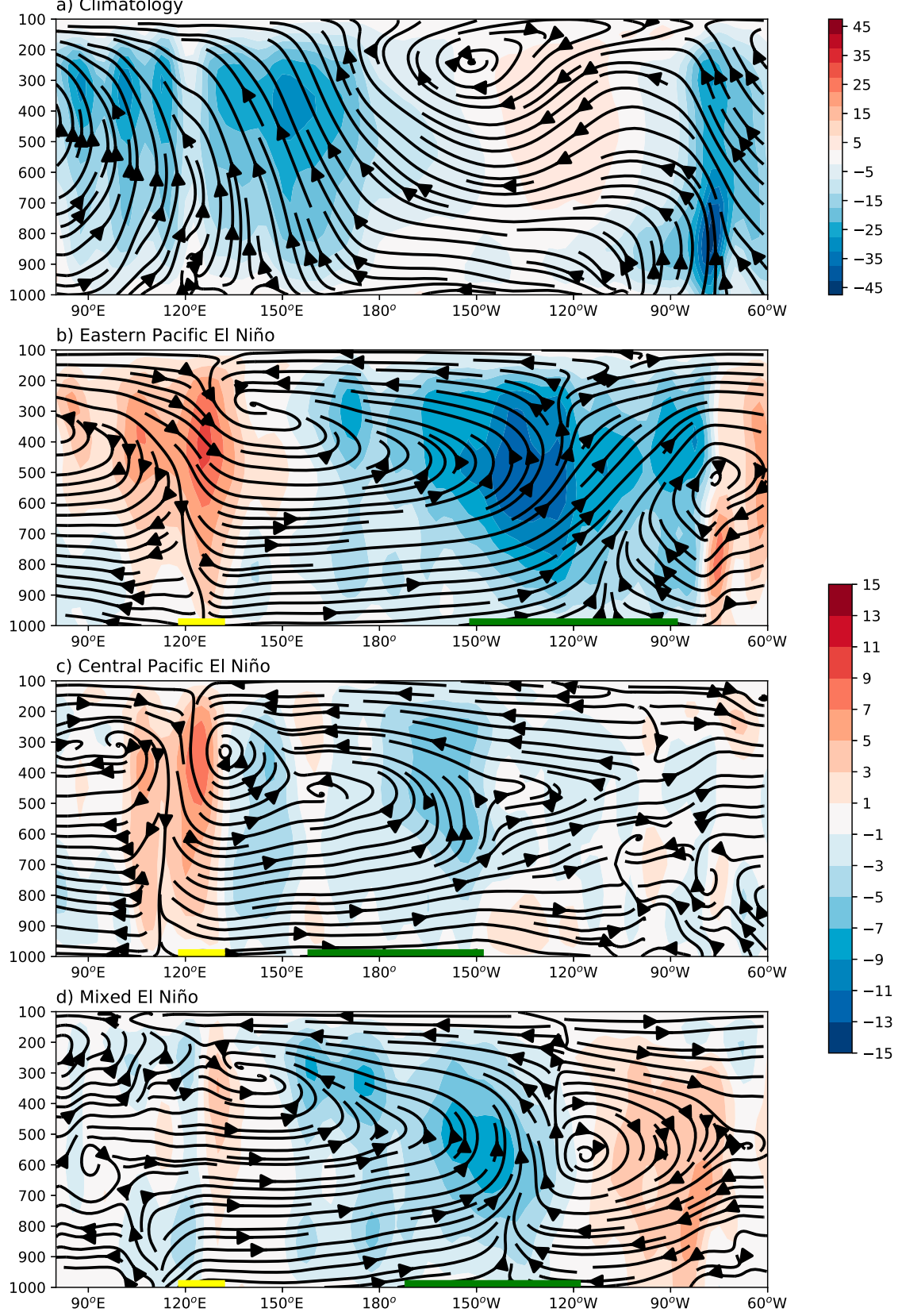

FIG. 10. (a) Climatological vertical velocity $\left(\mathrm{Pa} \mathrm{s}^{-1}\right)$ and streamlines averaged between the equator and $10^{\circ} \mathrm{N}$. Also shown are composites of vertical velocity anomalies $\left(\mathrm{Pa} \mathrm{s}^{-1}\right)$ and anomalous streamlines averaged between the equator and $10^{\circ} \mathrm{N}$ for (b) EPE, (c) CPE, and (d) ME. Vertical velocity anomalies at each pressure level are multiplied by 500 . Green solid lines indicate the Niño-3, Niño-4, and Niño-3.4 regions in (b), (c), and (d), respectively. Yellow solid lines denote the region between $120^{\circ}$ and $130^{\circ} \mathrm{E}$.

During EPE years, fewer TCs form west of $150^{\circ} \mathrm{E}$ (Fig. 3a), which reduces the frequency of TCs making landfall over most of the coastal countries in Southeast and East Asia except Japan. TCs forming east of $150^{\circ} \mathrm{E}$ are more likely to recurve poleward and threaten Japan, due to the reduced blocking effect of a weakened WPSH with both the western edge of the ridge and the ridge axis retreating to around $135^{\circ} \mathrm{E}$ (Fig. 12b). On the other hand, if these TCs happen to move westward, they experience unfavorable environmental conditions over the 


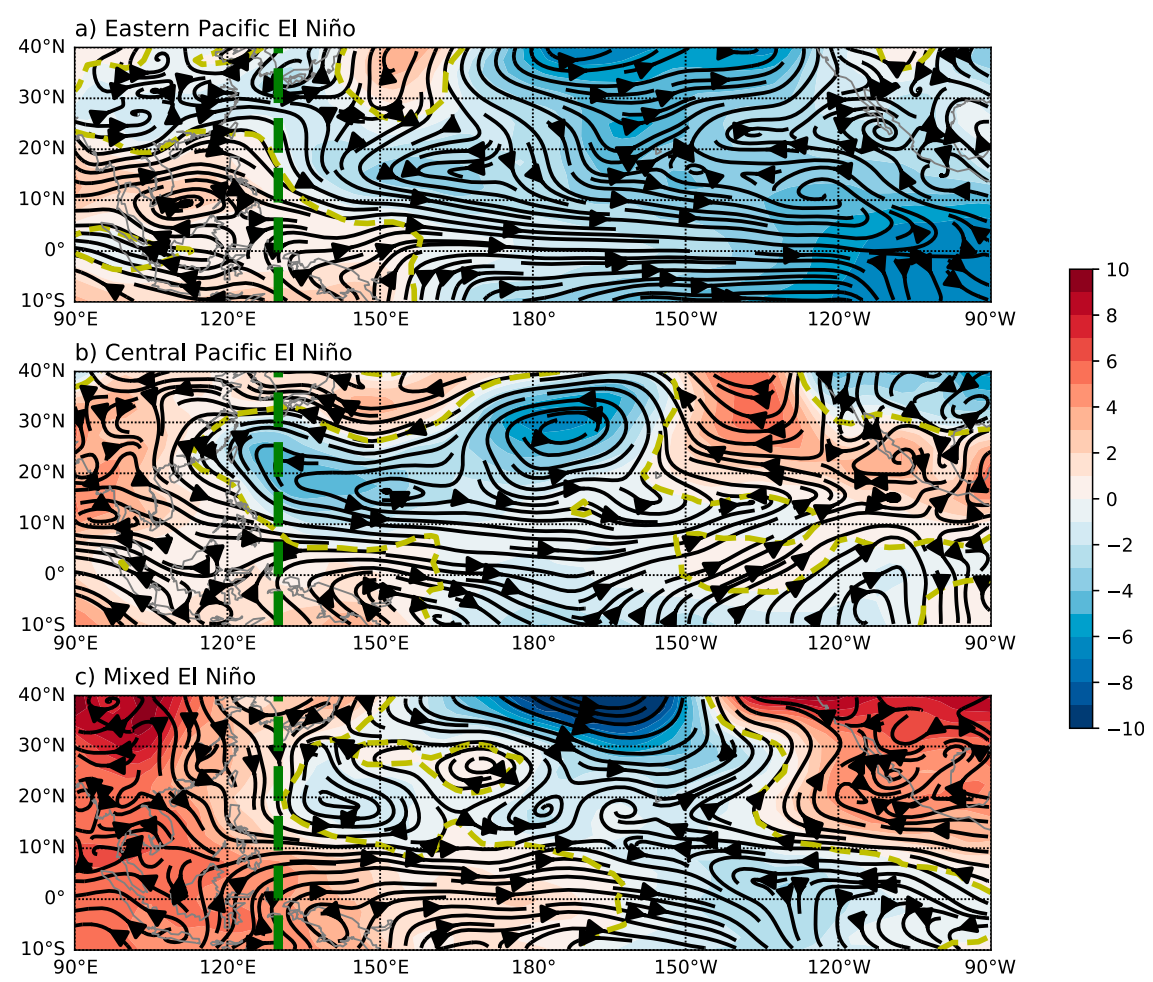

FIG. 11. Composites of eddy geopotential height anomalies (gpm) and anomalous streamlines at $850 \mathrm{hPa}$ for (a) EPE, (b) CPE, and (c) ME. Yellow dashed lines indicate the 0-gpm contour lines. The $130^{\circ} \mathrm{E}$ longitude line is highlighted by a green dashed line.

area around the Philippines (e.g., decreased RH600 as shown in Fig. 7c). Consequently, these TCs are less likely to survive to hit the coastal regions of Southeast Asia and South China.

During CPE years, since the WPSH is stronger and extends more westward than during EPE years (Fig. 12c), TCs are more likely to track farther westward, then recurve poleward near the continent and hit East Asia. Over the region north of $30^{\circ} \mathrm{N}$ and east of $130^{\circ} \mathrm{E}$, TCs experience some favorable conditions (greater MPI and lower SHR as shown in Figs. 8a,d) as well as some unfavorable conditions (lower RH600 and VOR850 as shown in Figs. 8b,c) due to the CPE event, increasing the uncertainty whether TCs survive or dissipate. In addition, more frequent TC genesis over the northwestern quadrant of the WNP likely increases the TC threat to East Asia, whereas less TC formation around the Philippines potentially leads to fewer TCs making landfall in Southeast Asia and South China (Fig. 3b).

During ME years, the WPSH is stronger than in CPE or EPE with both its western edge and the ridge axis extending farther west than in CPE or EPE (Fig. 12d), inhibiting TC recurvature and causing an increase in the number of TCs moving westward and making landfall over the Philippines. Note that the WPSH in ME is not simply the combination of the WPSH during EPE and
CPE. For those TCs that are tracking poleward, the enhanced SHR north of $25^{\circ} \mathrm{N}$ (Fig. 9g) accelerates TC dissipation, likely leading to fewer TCs threatening North China, the Korean peninsula, and Japan. Additionally, fewer TCs form west of $150^{\circ} \mathrm{E}$ (Fig. 3c), likely reducing the number of TCs making landfall over East Asia.

The WPSH corresponds to the subsiding branch of the Hadley circulation (Choi and Kim 2019). Given the strong relationship between the Walker circulation and the Hadley circulation over the Indo-Pacific warm pool region (Gagan and Thompson 2005), differences in anomalous descending motion around $120^{\circ} \mathrm{E}$ between different El Niño phases can induce different features in the local Hadley cell (Fig. 13). Similar anomalous Hadley cells occur in EPE and CPE years, with major anomalous downdrafts and updrafts near the equator and around $25^{\circ} \mathrm{N}$, respectively, which opposes the climatological Hadley circulation (Figs. 13a-c). The strength of the anomalous Hadley cell during EPE is much stronger than that during CPE, which is likely to be a result of the stronger and broader downward motion at lower latitudes. During EPE and CPE, there is anomalous ascending motion at lower and middle levels in the subtropics. The anomalous ascending motion from $20^{\circ}$ to $30^{\circ} \mathrm{N}$ along $130^{\circ} \mathrm{E}$ (Figs. 14a,b) induces the decreased lowlevel eddy geopotential height anomalies (Figs. 12b,c), likely 

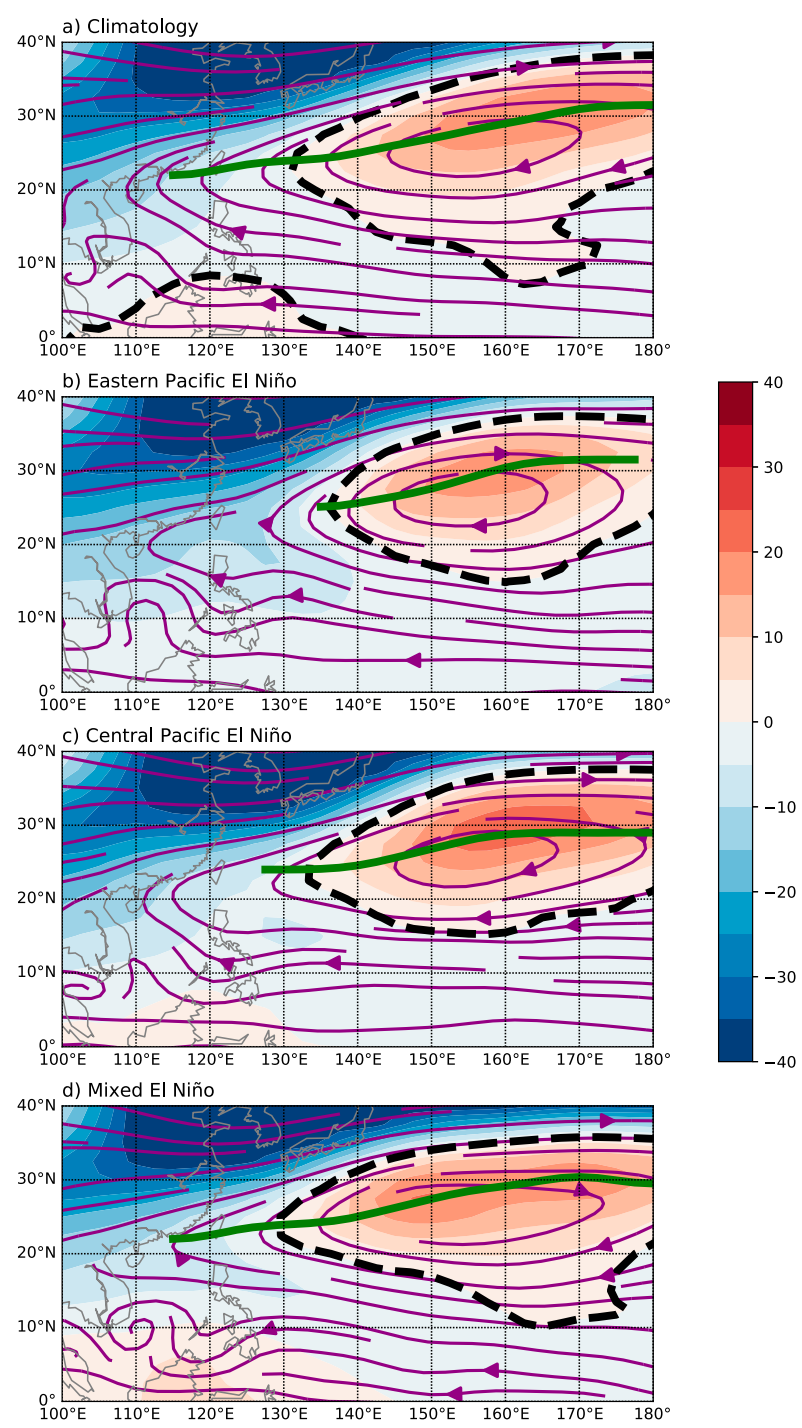

FIG. 12. 850-hPa eddy geopotential height (gpm) and 850-300$\mathrm{hPa}$ steering flow for (a) climatology, (b) EPE, (c) CPE, and (d) ME. Black dashed lines indicate the 0-gpm contour lines, which is used to define the extent of the western Pacific subtropical high. Green solid lines denote the ridge axis that is estimated by the maximum meridional gradient of the zonal winds and is terminated at a minimum of $1 \times 10^{-5} \mathrm{~s}^{-1}$.

causing an eastward shift of the WPSH. Consequently, we find more recurving TCs in EPE and CPE years. The retreat of the WPSH is farther eastward in EPE years, due to the stronger anomalous Hadley cell. This further induces more TCs recurving at farther east longitudes in EPE years.

There is also a distinct feature of an anomalous Hadley circulation in ME years (Fig. 13d). There are two anomalous cells with an ascending branch centered at around $10^{\circ} \mathrm{N}$ and two descending branches near the equator and north of $20^{\circ} \mathrm{N}$. Note that the descending flow north of $25^{\circ} \mathrm{N}$ during $\mathrm{ME}$ is of the same sign as the subsiding branch of the climatological Hadley circulation.
Local Hadley Circulation $\left(120^{\circ}-130^{\circ} \mathrm{E}\right)$
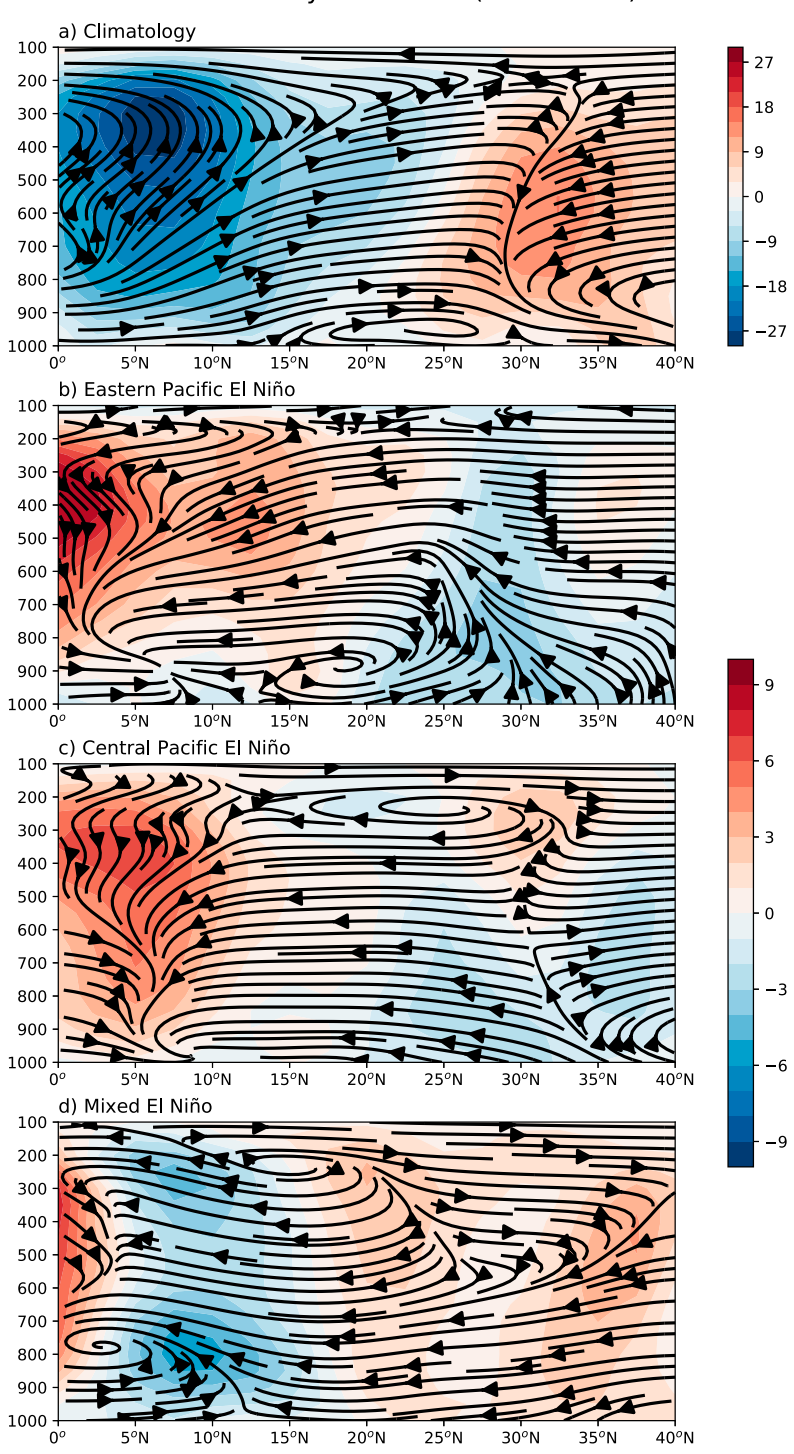

FIG. 13. (a) Climatological vertical velocity $\left(\mathrm{Pa} \mathrm{s}^{-1}\right)$ and streamlines averaged from $120^{\circ}$ to $130^{\circ} \mathrm{E}$. Also shown are composites of vertical velocity anomalies $\left(\mathrm{Pa} \mathrm{s}^{-1}\right)$ and anomalous streamlines averaged from $120^{\circ}$ to $130^{\circ} \mathrm{E}$ for (b) EPE, (c) CPE, and (d) ME. Vertical velocity anomalies at each pressure level are multiplied by 500 .

We speculate that the broad low-level downward anomalous flow centered near $20^{\circ} \mathrm{N}$ (Fig. 14c) increases the $850-\mathrm{hPa}$ eddy geopotential height anomalies west of $130^{\circ} \mathrm{E}$ (Fig. 12c), further strengthening the WPSH and leading to a westward extension of the WPSH ridge. As a result, TCs are more likely to more frequently take westward trajectories in ME years.

\section{Conclusions and discussions}

This study investigates the characteristics of WNP TC genesis and track for three different types of El Niño as 

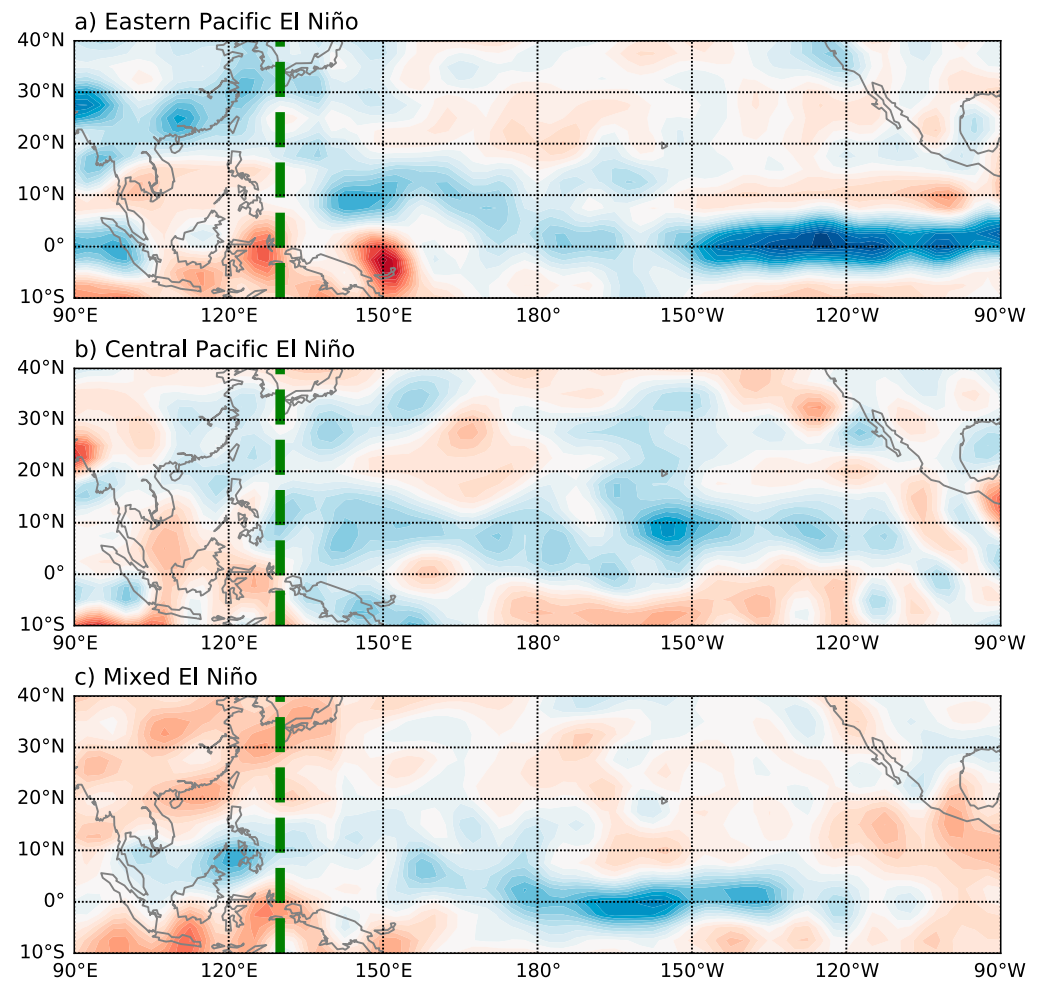

FIG. 14. Composites of 850 -hPa vertical velocity anomalies $\left(\times 10^{-2} \mathrm{~Pa} \mathrm{~s}^{-1}\right)$ for (a) EPE,

(b) $\mathrm{CPE}$, and (c) $\mathrm{ME}$. The $130^{\circ} \mathrm{E}$ longitude line is highlighted by a green dashed line.

well as the large-scale fields likely contributing to the observed differences in TC activity for these three $\mathrm{El}$ Niño types. The EPE, CPE, and ME cases over the period from 1970-2019 are categorized according to the June-November SSTAs in the Niño-3, Niño-4, and Niño-3.4 regions, respectively. These regions describe the location where the Pacific warming is maximized. To compare the characteristics of TC activity and largescale environments for each El Niño phase, composite analyses are made based on six EPE years, five CPE years, and five ME years.

In all three El Niño phases, TC genesis anomalies share similar features in that more TCs form over the eastern part of the WNP (east of $150^{\circ} \mathrm{E}$ ). However, there are considerable differences in TC genesis anomalies west of $150^{\circ} \mathrm{E}$. TC genesis is significantly suppressed and enhanced in EPE years and CPE years, respectively, whereas there are negative, but insignificant, genesis anomalies in ME years. The number of TCs forming west of $150^{\circ} \mathrm{E}$ tends to increase as the maximum in the tropical Pacific warm anomaly shifts from east to west.

There are also distinct features in WNP TC track density anomalies among the three El Niño cases. In EPE years, more TCs recurve farther away from the East Asian continent and subsequently are more likely to recurve into the open North Pacific Ocean or to make landfall in Japan. In CPE years, TCs are more likely to recurve closer to the coast and consequently threaten more East Asian countries. Compared with CPE and EPE events, the number of recurving TCs is reduced in ME years. Instead, a larger number of TCs move westward and make landfall in the Philippines. The observed ME track density anomaly pattern is not simply a combination of the TC track anomalies in EPE and CPE years.

El Niño's modulation of WNP TC genesis can be explained by changes in the large-scale environment. Over the eastern part of the WNP, increased VOR850 and decreased SHR both appear to significantly impact TC formation, regardless of the El Niño type. Increased MPI is also significantly favorable for TC genesis in CPE years, while RH600 is significantly favorable for TC genesis in EPE and ME years. Furthermore, midtropospheric dryness primarily suppresses TC genesis over the western half of the WNP during EPE, whereas enhanced VOR850 mainly favors TC genesis over the northwestern quadrant of the WNP during ME. Compared with Camargo et al. (2007b), which considered relative humidity and vorticity as important factors for modulating WNP TC activity, our study finds that the effects of SHR and MPI cannot be neglected over certain portions of the basin and for certain El Niño types. 
The anomalous Walker circulation exhibits different features for each El Niño type, with the maximum anomalous upward motion migrating westward as the peak SSTA warming shifts from east to west. All three El Niño types are characterized by anomalous ascending flow near the date line, which enhances TC development over the southeastern quadrant of the WNP. In EPE years, there is a broad anomalous cyclone over the central subtropical Pacific, with a horizontal trough along $160^{\circ} \mathrm{E}$ favoring $\mathrm{TC}$ genesis over the eastern part of the WNP. Although an anomalous low-level cyclonic circulation covers most of the WNP for both CPE and ME events, it induces more TCs over almost the entire basin during CPE, while a northwest-southeast-oriented trough (from approximately $20^{\circ} \mathrm{N}, 140^{\circ} \mathrm{E}$ to $10^{\circ} \mathrm{N}$, $160^{\circ} \mathrm{E}$ ) leads to more TC occurrences over the southeastern corner of the WNP in ME events.

El Niño also impacts WNP TC track through modulation of TC genesis locations as well as the steering flow. During EPE and CPE years, there is an eastward retreat of the WPSH, which further leads to more TCs recurving and making landfall over northern China, the Korean peninsula, and Japan. During ME years, the WPSH is strengthened and the ridge extends westward, causing more TCs to move westward and threaten the Philippines. The differences of the WPSH in the three El Niño phases can be linked to differences in the local Hadley circulation, which is strongly coupled to the Walker circulation over the Indo-Pacific warm pool region. The anomalous Walker circulation around $120^{\circ} \mathrm{E}$ is of different magnitudes for each ENSO type, with the strongest and weakest descending flow occurring in EPE years and ME years, respectively. The anomalous download motion over the subtropics in ME likely causes the westward extension of the WPSH, while anomalous upward motion over the subtropics in EPE and CPE events likely causes the eastward retreat of the WPSH.

It has been documented that SST changes in other basins (e.g., TNA and IO) can considerably impact the Walker circulation and the WPSH, further modulating WNP TC activity (Zhan et al. 2011; Hong et al. 2014; Huo et al. 2015; Cao et al. 2018; Jin and Huo 2018; Wang and Yu 2018; Cai et al. 2019; Chen et al. 2019). In this study, we find no significant SSTAs over the TNA region during any of the three El Niño phases, implying that WNP TC activity in these three El Niño phases is likely less influenced by changes in TNA SST. In addition, there are significant positive SSTAs over the eastern IO during EPE years, highlighting the linkage between the IOD and EPE. As noted by Zhan et al. (2011), ENSO significantly affects the east-west shift of the mean TC formation location, while the eastern IO SSTA influences TC formation for the entire WNP genesis region after removing the ENSO effect. The TC genesis anomaly pattern during EPE years in our study exhibits an east-west dipole pattern, meaning that the influence of SSTAs over the eastern IO is likely to be relatively small given the different El Niño phases examined.

Our results are based on a statistical analysis of a limited number of samples. The main findings need to be verified by numerical sensitivity experiments using different SST forcings. While we focus on the modulation of three types of El Niño events on WNP TC activity in this study, there are other ENSO flavors that exhibit distinct features (Johnson 2013), including several kinds of tropical Pacific cooling events (Yu and Kim 2013). How other flavors of ENSO affect WNP TC activity will be investigated in future research.

Acknowledgments. We would like to express our sincere thanks to three anonymous reviewers for their helpful comments on an earlier version of this manuscript. This work was jointly funded by the National Natural Science Foundation of China (61827901), the National Key Research and Development Program of China (2018YFC1507305), and the fifth period of the 2019 "333 Project" in Jiangsu Province of China. Klotzbach would like to acknowledge financial support from the G. Unger Vetlesen Foundation.

\section{REFERENCES}

Andreoli, R. V., S. S. de Oliveira, M. T. Kayano, J. Viegas, R. A. F. de Souza, and L. A. Candido, 2017: The influence of different El Niño types on the South American rainfall. Int. J. Climatol., 37, 1374-1390, https://doi.org/10.1002/joc.4783.

Ashok, K., and T. Yamagata, 2009: Climate change: The El Niño with a difference. Nature, 461, 481-484, https://doi.org/10.1038/ 461481a.

— , S. K. Behera, S. A. Rao, H. Weng, and T. Yamagata, 2007: El Niño Modoki and its possible teleconnection. J. Geophys. Res., 112, C11007, https://doi.org/10.1029/2006JC003798.

Bell, G. D., and Coauthors, 2000: Climate assessment for 1999. Bull. Amer. Meteor. Soc., 81, 1328, https://doi.org/10.1175/ 1520-0477(2000)081<1328:CAF>2.3.CO;2.

Cai, W., and Coauthors, 2019: Pantropical climate interactions. Science, 363, eaav4236, https://doi.org/10.1126/science.aav4236.

Camargo, S. J., and A. H. Sobel, 2005: Western North Pacific tropical cyclone intensity and ENSO. J. Climate, 18, 29963006, https://doi.org/10.1175/JCLI3457.1.

_ A. W. Robertson, S. J. Gaffney, S. Smyth, and M. Ghil, 2007a: Cluster analysis of typhoon tracks. Part I: Large-scale circulation and ENSO. J. Climate, 20, 3654-3676, https://doi.org/ 10.1175/JCLI4203.1.

_ K. A. Emanuel, and A. H. Sobel, 2007b: Use of a genesis potential index to diagnose ENSO effects on tropical cyclone genesis. J. Climate, 20, 4819-4834, https://doi.org/10.1175/JCLI4282.1.

Cao, X., R. Wu, and X. Xiao, 2018: A new perspective of intensified impact of El Niño-Southern Oscillation Modoki on tropical cyclogenesis over the western North Pacific around 1990s. Int. J. Climatol., 38, 4262-4275, https://doi.org/10.1002/joc.5667. 
Chan, J. C. L., 1985: Tropical cyclone activity in the northwest Pacific in relation to the El Niño/Southern Oscillation phenomenon. Mon. Wea. Rev., 113, 599-606, https://doi.org/ 10.1175/1520-0493(1985)113<0599:TCAITN > 2.0.CO;2. , 2000: Tropical cyclone activity over the western North Pacific associated with El Niño and La Niña events. J. Climate, 13, 2960-2972, https://doi.org/10.1175/1520-0442(2000)013<2960: TCAOTW $>2.0 . \mathrm{CO} ; 2$.

_ 2005: Interannual and interdecadal variations of tropical cyclone activity over the western North Pacific. Meteor. Atmos. Phys., 89, 143-152, https://doi.org/10.1007/s00703-005-0126-y.

Chen, G., and C.-Y. Tam, 2010: Different impacts of two kinds of Pacific Ocean warming on tropical cyclone frequency over the western North Pacific. Geophys. Res. Lett., 37, L01803, https:// doi.org/10.1029/2009GL041708.

Chen, M., J.-Y. Yu, X. Wang, and W. Jiang, 2019: The changing impact mechanisms of a diverse El Niño on the western Pacific subtropical high. Geophys. Res. Lett., 46, 953-962, https:// doi.org/10.1029/2018GL081131.

Choi, W., and K.-Y. Kim, 2019: Summertime variability of the western North Pacific subtropical high and its synoptic influences on the East Asian weather. Sci. Rep., 9, 7865, https:// doi.org/10.1038/s41598-019-44414-w.

Chu, J.-H., C. R. Sampson, A. S. Levine, and E. Fukada, 2002: The Joint Typhoon Warming Center tropical cyclone best-tracks, 1945-2000. NRL Tech. Rep. NRL/MR/7540-02-16, 22 pp.

Chu, P.-S., J.-H. Kim, and Y. R. Chen, 2012: Have steering flows in the western North Pacific and the South China Sea changed over the last 50 years? Geophys. Res. Lett., 39, L10704, https:// doi.org/10.1029/2012GL051709.

Emanuel, K. A., 1988: The maximum intensity of hurricanes. J. Atmos. Sci., 45, 1143-1155, https://doi.org/10.1175/15200469(1988)045<1143:TMIOH > 2.0.CO;2.

_ 2018: 100 years of progress in tropical cyclone research. $A$ Century of Progress in Atmospheric and Related Sciences: Celebrating the American Meteorological Society Centennial, Meteor. Monogr., No. 59, Amer. Meteor. Soc., https://doi.org/ 10.1175/AMSMONOGRAPHS-D-18-0016.1.

_ , and D. S. Nolan, 2004: Tropical cyclone activity and global climate. 26th Conf. on Hurricanes and Tropical Meteorology, Miami, FL, Amer. Meteor. Soc., 240-241.

Gagan, M. K., and L. G. Thompson, 2005: Evolution of the IndoPacific warm pool and Hadley-Walker circulation since the last deglaciation. The Hadley Circulation: Present, Past and Future, H. F. Diaz and R. S. Bradley, Eds., Kluwer Academic, 289-312.

Giese, B. S., and S. Ray, 2011: El Niño variability in simple ocean data assimilation (SODA), 1871-2008. J. Geophys. Res., 116, C02024, https://doi.org/10.1029/2010JC006695.

Ha, K.-J., S.-J. Yoon, K.-S. Yun, J.-S. Kug, Y.-S. Jang, and J. C. L. Chan, 2012: Dependency of typhoon intensity and genesis locations on El Niño phase and SST shift over the western North Pacific. Theor. Appl. Climatol., 109, 383-395, https:// doi.org/10.1007/s00704-012-0588-z.

Ham, Y.-G., J.-S. Kug, J.-Y. Park, and F.-F. Jin, 2013a: Sea surface temperature in the north tropical Atlantic as a trigger for El Niño/Southern Oscillation events. Nat. Geosci., 6, 112-116, https://doi.org/10.1038/ngeo1686.

,,-- and $-2013 \mathrm{~b}$ : Two distinct roles of Atlantic SSTs in ENSO variability: North tropical Atlantic SST and Atlantic Niño. Geophys. Res. Lett., 40, 4012-4017, https://doi.org/ 10.1002/grl.50729.

Hong, C.-C., T.-C. Chang, and H.-H. Hsu, 2014: Enhanced relationship between the tropical Atlantic SST and the summer- time western North Pacific subtropical high after the early 1980s. J. Geophys. Res. Atmos., 119, 3715-3722, https:// doi.org/10.1002/2013JD021394.

Huang, B., and Coauthors, 2017: Extended Reconstructed Sea Surface Temperature, version 5 (ERSSTv5): Upgrades, validations, and intercomparisons. J. Climate, 30, 8179-8205, https://doi.org/10.1175/JCLI-D-16-0836.1.

Huang, Y. Y., H. J. Wang, K. Fan, and Y. Q. Gao, 2015: The western Pacific subtropical high after the 1970s: Westward or eastward shift? Climate Dyn., 44, 2035-2047, https://doi.org/ 10.1007/s00382-014-2194-5.

Huo, L., P. Guo, S. N. Hameed, and D. Jin, 2015: The role of tropical Atlantic SST anomalies in modulating western North Pacific tropical cyclone genesis. Geophys. Res. Lett., 42, 23782384, https://doi.org/10.1002/2015GL063184.

Jin, C.-S., C.-H. Ho, J.-H. Kim, D.-K. Lee, D.-H. Cha, and S.-W. Yeh, 2013: Critical role of northern off-equatorial sea surface temperature forcing associated with central Pacific El Niño in more frequent tropical cyclone movements toward East Asia. J. Climate, 26, 2534-2545, https://doi.org/10.1175/JCLI-D-12-00287.1.

Jin, D., and L. Huo, 2018: Influence of tropical Atlantic sea surface temperature anomalies on the East Asian summer monsoon. Quart. J. Roy. Meteor. Soc., 144, 1490-1500, https://doi.org/10.1002/qj.3296.

Johnson, N. C., 2013: How many ENSO flavors can we distinguish? J. Climate, 26, 4816-4827, https://doi.org/10.1175/JCLI-D-1200649.1.

Kalnay, E., and Coauthors, 1996: The NCEP/NCAR 40-Year Reanalysis Project. Bull. Amer. Meteor. Soc., 77, 437-471, https://doi.org/10.1175/1520-0477(1996)077<0437:TNYRP> 2.0.CO;2

Kao, H.-Y., and J.-Y. Yu, 2009: Contrasting eastern Pacific and central Pacific types of ENSO. J. Climate, 22, 615-632, https:// doi.org/10.1175/2008JCLI2309.1.

Kim, H.-M., P. J. Webster, and J. A. Curry, 2011: Modulation of North Pacific tropical cyclone activity by three phases of ENSO. J. Climate, 24, 1839-1849, https://doi.org/10.1175/ 2010JCLI3939.1.

Klotzbach, P. J., and C. W. Landsea, 2015: Extremely intense hurricanes: Revisiting Webster et al. (2005) after 10 years. J. Climate, 28, 7621-7629, https://doi.org/10.1175/JCLI-D-150188.1.

Knapp, K. R., M. C. Kruk, D. H. Levinson, H. J. Diamond, and C. J. Neuman, 2010: The International Best Track Archive for Climate Stewardship (IBTrACS). Bull. Amer. Meteor. Soc., 91, 363-376, https://doi.org/10.1175/2009BAMS2755.1.

Knutson, T., and Coauthors, 2019: Tropical cyclones and climate change assessment. Part I: Detection and attribution. Bull. Amer. Meteor. Soc., 100, 1987-2007, https://doi.org/10.1175/ BAMS-D-18-0189.1.

and Coauthors, 2020: Tropical cyclones and climate change assessment. Part II. Projected response to anthropogenic warming. Bull. Amer. Meteor. Soc., 101, E303-E322, https:// doi.org/10.1175/BAMS-D-18-0189.1.

Kug, J.-S., F.-F. Jin, and S.-I. An, 2009: Two types of El Niño events: Cold-tongue El Niño and warm-pool El Niño. J. Climate, 22, 1499-1515, https://doi.org/10.1175/2008JCLI2624.1.

Lander, M. A., 1994: An exploratory analysis of the relationship between tropical storm formation in the western North Pacific and ENSO. Mon. Wea. Rev., 122, 636-651, https://doi.org/ 10.1175/1520-0493(1994)122<0636:AEAOTR > 2.0.CO;2.

Li, R. C. Y., and W. Zhou, 2012: Changes in western Pacific tropical cyclones associated with the El Niño-Southern Oscillation 
cycle. J. Climate, 25, 5864-5878, https://doi.org/10.1175/JCLID-11-00430.1.

Li, X., C. Li, J. Ling, and Y. Tan, 2015: The relationship between contiguous El Niño and La Niña revealed by self-organizing maps. J. Climate, 28, 8118-8134, https://doi.org/10.1175/JCLID-15-0123.1.

Murphy, B. F., S. B. Power, and S. McGree, 2014: The varied impacts of El Niño-Southern Oscillation on Pacific island climates. J. Climate, 27, 4015-4036, https://doi.org/10.1175/JCLID-13-00130.1.

Patricola, C. M., S. J. Camargo, P. J. Klotzbach, R. Saravanan, and P. Chang, 2018: The influence of ENSO flavors on western North Pacific tropical cyclone activity. J. Climate, 31, 53955416, https://doi.org/10.1175/JCLI-D-17-0678.1.

Philander, S. G., 1990: El Niño, La Niña, and the Southern Oscillation. Academic Press, 293 pp.

Pradhan, P., B. Preethi, K. Ashok, R. Krishnan, and A. Sahai, 2011: Modoki, Indian Ocean dipole, and western North Pacific typhoons: Possible implications for extreme events. J. Geophys. Res., 116, D18108, https://doi.org/10.1029/2011JD015666.

Rasmusson, E. M., and T. H. Carpenter, 1982: Variations in tropical sea surface temperature and surface wind fields associated with the Southern Oscillation/El Niño. J. Climate, 110, 354-384, https:// doi.org/10.1175/1520-0493(1982)110<0354:VITSST>2.0.CO;2.

Saunders, M. A., R. E. Chandler, C. J. Merchant, and F. P. Roberts, 2000: Atlantic hurricanes and NW Pacific typhoons: ENSO spatial impacts on occurrence and landfall. Geophys. Res. Lett., 27, 1147-1150, https://doi.org/10.1029/1999GL010948.

Snedecor, G. W., and W. G. Cochran, 1989: Statistical Methods. 8th ed. Iowa State University Press, 503 pp.

Song, J., and P. J. Klotzbach, 2019: Relationship between the Pacific-North American pattern and the frequency of tropical cyclones over the western North Pacific. Geophys. Res. Lett., 46, 6118-6127, https://doi.org/10.1029/2019GL082925.

Stuecker, M. F., 2018: Revisiting the Pacific meridional mode. Sci. Rep., 8, 3216, https://doi.org/10.1038/s41598-018-21537-0.

Timmermann, A., and Coauthors, 2018: El Niño-Southern Oscillation complexity. Nature, 559, 535-545, https://doi.org/10.1038/s41586018-0252-6.

Trenberth, K. E., 1997: The definition of El Niño. Bull. Amer. Meteor. Soc., 78, 2771-2778, https://doi.org/10.1175/15200477(1997)078<2771:TDOENO > 2.0.CO;2.

Walsh, K. J. E., and Coauthors, 2016: Tropical cyclones and climate change. Wiley Interdiscip. Rev.: Climate Change, 7, 65-89, https://doi.org/10.1002/WCC.371.

—, S. J. Camargo, T. R. Knutson, J. Kossin, T.-C. Lee, H. Murakami, and C. Patricola, 2019: Tropical cyclones and climate change. Trop. Cyclone Res. Rev., 8, 240-250, https:// doi.org/10.1016/j.tcrr.2020.01.004.

Wang, B., and J. C. L. Chan, 2002: How strong ENSO events affect tropical storm activity over the western North Pacific. J. Climate, 15, 1643-1658, https://doi.org/10.1175/1520-0442(2002)015<1643: HSEEAT $>2.0 . \mathrm{CO} ; 2$.

_ B. Xiang, and J.-Y. Lee, 2013: Subtropical high predictability establishes a promising way for monsoon and tropical storm predictions. Proc. Natl. Acad. Sci. USA, 110, 2718-2722, https://doi.org/10.1073/pnas.1214626110.

Wang, C., C. Li, M. Mu, and W. Duan, 2013: Seasonal modulations of different impacts of two types of ENSO events on tropical cyclone activity in the western North Pacific. Climate Dyn., 40, 2887-2902, https://doi.org/10.1007/s00382-012-1434-9.
_ C. Deser, J.-Y. Yu, P. DiNezio, and A. Clement, 2017: El Niño and Southern Oscillation (ENSO): A review. Coral Reefs of the Eastern Tropical Pacific: Persistence and Loss in a Dynamic Environment, P. W. Glynn, D. P. Manzello, and I. C. Enoch, Eds., Coral Reefs of the World Series, Vol. 8, Springer, 85-106.

Wang, L., 2016: Contrasting two spring SST predictors for the number of western North Pacific tropical cyclones. Atmos. Oceanic Sci. Lett., 9, 420-427, https://doi.org/10.1080/16742834.2016.1231009.

— , and J.-Y. Yu, 2018: A recent shift in the monsoon centers associated with the tropospheric biennial oscillation. J. Climate, 31, 325-340, https://doi.org/10.1175/JCLI-D-17-0349.1.

,$- \ldots$, and H. Paek, 2017: Enhanced biennial variability in the Pacific due to Atlantic capacitor effect. Nat. Commun., 8, 14887, https://doi.org/10.1038/ncomms14887.

Wu, L., H. Zhang, J. Chen, and T. Feng, 2018: Impact of two types of El Niño on tropical cyclones over the western North Pacific: Sensitivity to location and intensity of Pacific warming. J. Climate, 31, 1725-1742, https://doi.org/10.1175/JCLI-D-170298.1.

Wu, M. C., W. L. Chang, and W. M. Leung, 2004: Impacts of El Niño-Southern Oscillation events on tropical cyclone landfalling activity in the western North Pacific. J. Climate, 17, 1419-1428, https://doi.org/10.1175/1520-0442(2004)017<1419: IOENOE $>2.0 . \mathrm{CO} ; 2$.

Yeh, S.-W., J.-S. Kug, B. Dewitte, M.-H. Kwon, B. P. Kirtman, and F.-F. Jin, 2009: El Niño in a changing climate. Nature, $\mathbf{4 6 1}$, 511-514, https://doi.org/10.1038/nature08316.

Yu, J.-Y., and S. T. Kim, 2013: Identifying the types of major El Niño events since 1870. Int. J. Climatol., 33, 2105-2112, https:// doi.org/10.1002/joc.3575.

— Y Y. Zou, S. T. Kim, and T. Lee, 2012: The changing impact of El Niño on US winter temperatures. Geophys. Res. Lett., 39, L15702, https://doi.org/10.1029/2012GL052483.

Yuan, Y., and C. Y. Li, 2008: Decadal variability of the IODENSO relationship. Chin. Sci. Bull., 53, 1745-1752, https:// doi.org/10.1007/s11434-008-0196-6.

— - S. Yang, and Z. Zhang, 2012: Different evolutions of the Philippine Sea anticyclone between the eastern and central Pacific El Niño: Possible effects of Indian Ocean SST. J. Climate, 25, 7867-7883, https://doi.org/10.1175/JCLI-D-12-00004.1.

Zhan, R., Y. Wang, and X. Lei, 2011: Contributions of ENSO and east Indian Ocean SSTA to the interannual variability of northwest Pacific tropical cyclone frequency. J. Climate, 24, 509-521, https://doi.org/10.1175/2010JCLI3808.1.

— $—$, and M. Wen, 2013: The SST gradient between the southwestern Pacific and the western Pacific warm pool: A new factor controlling the northwestern Pacific tropical cyclone genesis frequency. J. Climate, 26, 2408-2415, https:// doi.org/10.1175/JCLI-D-12-00798.1.

Zhang, W., H.-F. Graf, Y. Leung, and M. Herzog, 2012: Different El Niño types and tropical cyclone landfall in East Asia. J. Climate, 25, 6510-6523, https://doi.org/10.1175/JCLI-D-1100488.1.

Zhao, H., and C. Wang, 2019: On the relationship between ENSO and tropical cyclones in the western North Pacific during the boreal summer. Climate Dyn., 52, 275-288, https://doi.org/ 10.1007/s00382-018-4136-0.

- L. Wu, and W. Zhou, 2010: Assessing the influence of the ENSO on tropical cyclone prevailing tracks in the western North Pacific. Adv. Atmos. Sci., 27, 1361-1371, https://doi.org/ 10.1007/s00376-010-9161-9. 